\title{
28. PALYNOSTRATIGRAPHY OF THE BERRIASIAN TO CENOMANIAN SEQUENCE AT DEEP SEA DRILLING PROJECT SITE 535, LEG 77, SOUTHEASTERN GULF OF MEXICO ${ }^{1}$
}

\author{
L. A. Riley, ${ }^{2}$ Gearhart Geodata Services Limited, Kirkhill Industrial Estate, Dyce, Scotland \\ and \\ J. P. G. Fenton, Robertson Research International Limited, Llanrhos, Gwynedd, North Wales
}

\begin{abstract}
One hundred twenty-seven samples from DSDP Cores 535-18 to 535-79 have been analyzed palynologically and dated using dinoflagellate cysts. The taxa recorded indicate the presence of sediments of late Berriasian/late Valanginian (Sections 535-79-1 to 535-55-6) and Hauterivian (Sections 535-55-4 to 535-47-1) age. These sediments are unconformably overlain by Aptian deposits (Sections 535-46-2 to 535-43-3). Sections 535-43-2 to 535-18-1 yielded palynofloras of Aptian to Albian age. Ammonite evidence (Young, this volume), however, suggests reworking of these assemblages into Cenomanian deposits.
\end{abstract}

\section{INTRODUCTION}

Leg 77 of the Glomar Challenger was located in the western straits of Florida, southeastern Gulf of Mexico. The drilling conducted during the Leg is part of an overall program to study the evolution of the western North Atlantic passive margin, and to investigate the Mesozoic and Cenozoic history of the area.

\section{PALYNOLOGIC RESULTS}

\section{General Discussion}

The Cretaceous sequence (Berriasian-Cenomanian) at Site 535 yields rich palynofloras, containing varying proportions of dinoflagellate cysts, acritarchs, chlorophycean algae and miospores. These palynomorphs occur in association with relatively large numbers of microforaminiferal test-linings and tintinnid loricas. Marine microplankton dominate throughout the sequence, with terrestrially derived miospores making only minor contributions to the assemblages.

Miospore assemblages are relatively homogeneous in composition and display low taxonomic diversity. Pollen of gymnosperm origin predominate, in particular longranging species of Callialasporites, Classopollis and bisaccates. Within the late Berriasian-Aptian interval Classopollis is the most numerous miospore, reticulate angiosperm pollen first appearing in the Cenomanian.

Foraminiferal test-linings are encountered in very high numbers throughout the Cretaceous at Site 535, being especially prominant in the late Berriasian-early Valanginian and Aptian-Cenomanian intervals.

Throughout the late Berriasian-Hauterivian, tintinnid loricas are consistently observed. They occasionally occur in large numbers, especially within the late Berriasian-early Valanginian.

\footnotetext{
1 Buffler, R. T., Schlager, W., et al., Init. Repts. DSDP, 77: Washington (U.S. Govt. Printing Office).

2 Present address: Gearhart Geoconsultants Limited, Dyce, Aberdeen, Scotland.
}

Preservation of individual palynomorphs is generally good, and amorphous organic matter is the dominant kerogen throughout. Terrestrially derived kerogen components (structured vitrinite and inertinite, plant cuticles, and miospores) are present in only minor quantities.

\section{Stratigraphy}

Emphasis during the course of this study has been on palynomorphs of marine origin, especially dinoflagellate cysts. Dating is by comparison with known stratigraphic ranges established in accurately dated European onshore sections and local ranges established at previous DSDP sites in the North Atlantic. This information is to be found in the following publications which deal with various aspects of the onshore European and offshore Atlantic Lower Cretaceous: Davey [1978 (Aptian), 1979b (Portlandian-Barremian), 1979a (Aptian-Albian)]; Davey and Verdier [1971, 1973, 1974 (Aptian-Albian)]; Duxbury [1977 (Berriasian-Barremian)]; Fisher and Riley [1980 (Kimmeridgian-Valanginian)]; Habib [1972 (Oxfordian-Cenomanian), 1978 (Berriasian-Albian)]; Verdier [1975 (Barremian-Albian)]; Williams and Bujak [1979 (Berriasian-Hauterivian)]; and unpublished research by the authors on both onshore and offshore $\mathrm{Eu}-$ ropean Lower Cretaceous.

The stratigraphic distribution and relative abundance of the marine palynomorphs recovered during this investigation are shown on Figs. 1-4. In addition, the stratigraphic ranges of 49 "key taxa," which have been chosen for their chronostratigraphic potential, are shown on Fig. 5.

\section{Late Berriasian-Late Valanginian (Sections 535-79-1 to 535-55-6)}

Assemblages are characterized by large percentages of Chytroeisphaeridia sp. A, Diacanthum hollisteri, Gonyaulacysta helicoidea, Hystrichodinium pulchrum, $H$. aff. pulchrum, Tanyosphaeridium boletum, and Polysphaeridium warrenii. Microforaminiferal test-linings and large leiospheres are also conspicuous components. Many of 


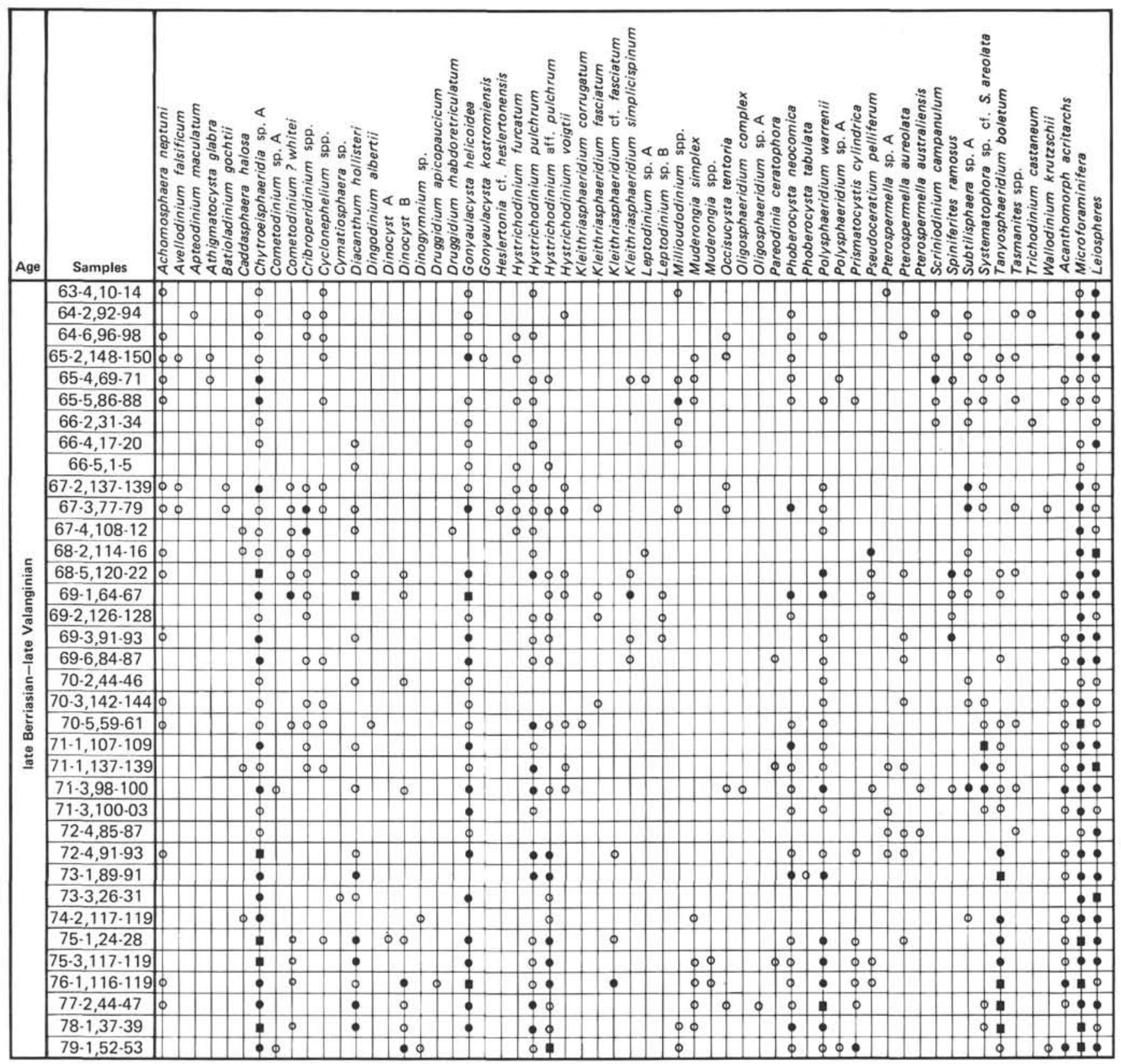

Figure 1. Distribution of marine microplankton in Section 535-79-1 to 535-63-4; open circle indicates taxon present, solid circle indicates taxon common, solid square indicates taxon abundant. Sample numbers expressed as core-section, interval in $\mathrm{cm}$.

the taxa encountered are either long ranging or not known from the Lower Cretaceous-type localities in Europe. Broad similarities are, however, seen with the dinoflagellate cyst assemblages present at Sites 391 (Habib, 1978) and 416 (Williams and Bujak, 1979).

Species first appearing in the European upper Berriasian (Davey, 1979b) and which occur in the basal part of this interval include Achomosphaera neptuni, Muderongia simplex, Phoberocysta neocomica, and Pseudoceratium pelliferum. Some degree of similarity with the European upper Berriasian is also afforded by the occurrence of Kleithriasphaeridium cf. fasciatum and variably spinate/tabulate cavate cysts (including Muderongia sp. cf. M. simplex of Habib, 1978) included here within $M$. simplex or $P$. neocomica.
By far the strongest affinities are, however, with the earliest Cretaceous assemblages reported by Habib (1978) from the Blake-Bahama Basin. Druggidium apicopaucicum first appears in Sample 535-76-1, 116-119 cm, the first (lowest) appearance of this species defining the boundary between Habib's $(1977,1978)$ Biorbifera johnewingii and Druggidium apicopaucicum zones. The zonal index $B$. johnewingii is conspicuous by its absence at Site 535. By comparison with Habib's (1978) data, Sample $535-76-1,116-119 \mathrm{~cm}$ is tentatively considered to approximate the horizon of the Berriasian/Valanginian boundary.

The first occurrence of Spiniferites ramosus in Sample 535-71-3, 98-100 cm indicates an age no older than Valanginian at this level, as this taxon is considered by 


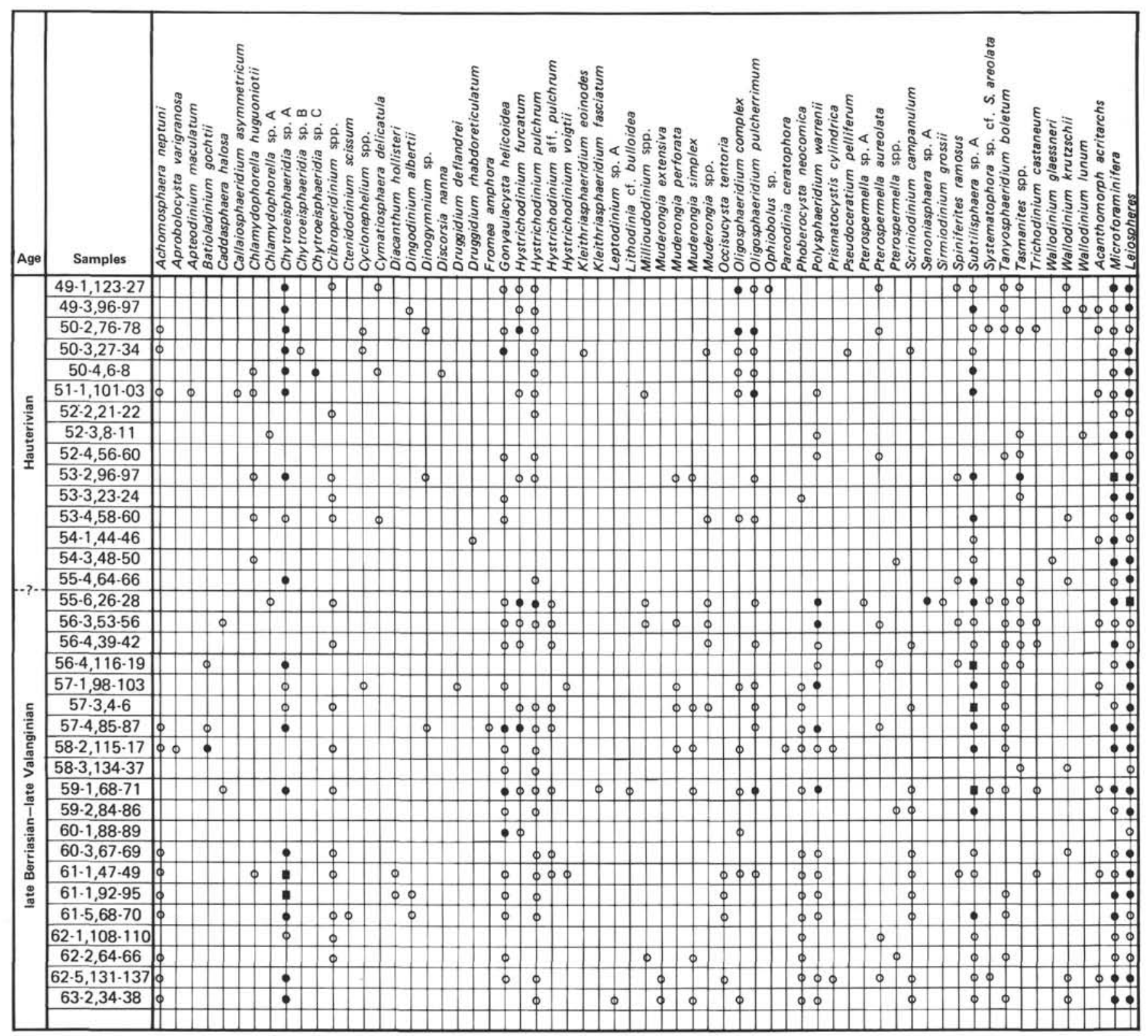

Figure 2. Distribution of marine microplankton in Sections 535-63-2 to 535-49-1. See Figure 2 for symbols and explanation of sample numbers.

Davey (1979b) not to occur in pre-Valanginian sediments. In addition, Kleithriasphaeridium simplicispinum, which first occurs in Section 535-69-6, is reported to make its stratigraphic appearance within the lower Valanginian (Davey, 1979b).

The assemblages recovered from above Section 53568-5 are readily differentiated from the underlying assemblages by an abrupt reduction in numbers of $D$. hollisteri, G. helicoidea, $H$. pulchrum, $P$. warrenii, and $T$. boletum. These features, in association with the occurrence of the taxa discussed below, tentatively suggest a late Valanginian age for Section 535-68-2 to 535-55-6. Within this subinterval several species are stratigraphically important and include, in alphabetical order, those listed below:

1. Aprobolocysta varigranosa has a first stratigraphic occurrence within the latest Valanginian of eastern
England (Duxbury, 1977) and is only present in Section 535-58-2.

2. Gonyaulacysta kostromiensis occurs, but rarely, at Site 535; its earliest occurrence is in Sample 535-65-2, $148-150 \mathrm{~cm}$. In eastern England this species occurs as low as the basal Hauterivian (Duxbury, 1977), but has been reported from the Valanginian of northern Canada (McIntyre and Brideaux, 1980).

3. Hystrichodinium furcatum has a first stratigraphic occurrence at the base of the Hauterivian in eastern England, although it has been encountered in Valanginian assemblages from northwest Europe (Riley, pers. obs.). It occurs throughout this interval, having a base in Section 535-67-4.

4. Muderongia extensiva is restricted to the upper Valanginian-lowermost Hauterivian of eastern England (Duxbury, 1977), and occurs rarely in Cores 63 and 62. 


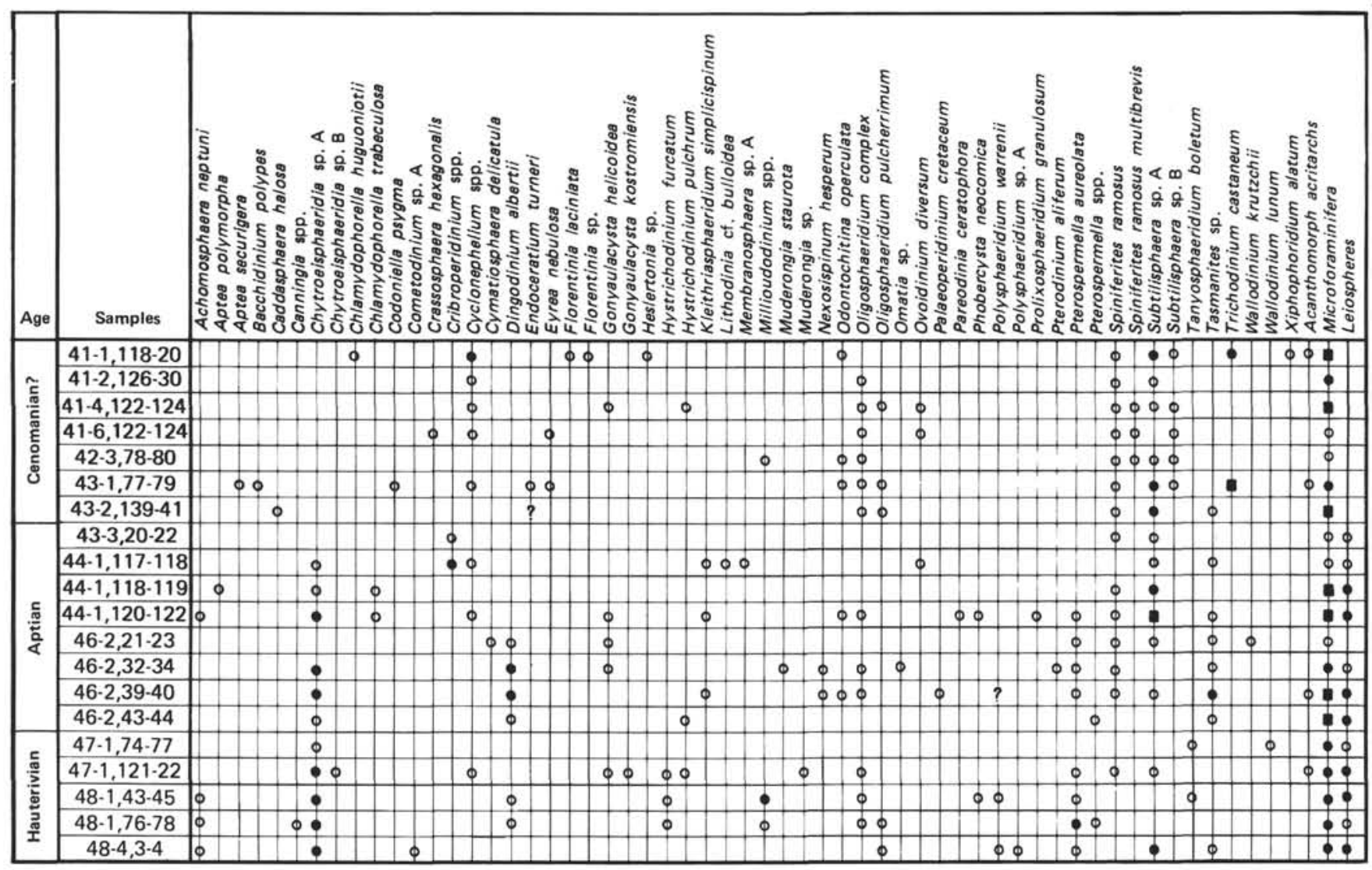

Figure 3. Distribution of marine microplankton in Sections 535-48-4 to 535-41-1. See Figure 2 for symbols and explanation of sample numbers.

5. Scriniodinium campanulum first appears in the Berriasian at Site 416 (Williams and Bujak, 1979), in the Valanginian at Sites 391 and 105 (Habib, 1972, 1978) and in Section 535-66-2 in this study. It is often a significant component of European upper Valanginian-lower Hauterivian assemblages (Riley, pers. obs.).

6. Subtilisphaera sp. A becomes a prominent component of many assemblages in this interval, and continued to be numerically significant in overlying intervals. In northwestern Europe this genus is generally considered not to occur in pre-Hauterivian sediments (Duxbury, 1977; Davey, 1979b), although large numbers of the genus have been encountered in subsurface sections, dated as Valanginian, in the Gulf of Mexico and onshore U.S. Gulf Coast (C. N. Denison, pers. comm., 1981).

This subinterval also contains the highest stratigraphic occurrences of Diacanthum hollisteri (Section 53561-1) and Leptodinium sp. A (Section 535-63-2). Habib $(1972,1978)$ considers $D$. hollisteri to range no younger than Valanginian at Sites 391 and 105, whereas both species make their last appearance within the Valanginian at Site 416 (Williams and Bujak, 1979).

\section{Valanginian/Hauterivian Boundary}

This boundary cannot be defined on palynologic criteria with any degree of accuracy because of the paucity of reliable datum horizons or key species in the European area. Over a wide geographic area throughout western Europe, the Valanginian/Hauterivian boundary is typically represented within a condensed sedimentary sequence. In onshore Western Europe and the Russian Platform the boundary is usually coincident with a major lithologic change and a corresponding, often abrupt, change in character and composition of dinoflagellate cyst assemblages (Riley, pers. obs.). These may be related to a major eustatic event (Rawson and Riley, 1982).

A significant lithologic change is evident in Section 535-55-5, and this equates with the last occurrence of Hystrichodinium aff. pulchrum, an abrupt decrease in numbers of Polysphaeridium warrenii and a reduction in abundance and frequency of Phoberocysta neocomi$c a$. These features are, by broad analogy with the European area, considered to approximate the Valanginian/ Hauterivian boundary.

\section{Hauterivian (Section 535-55-4 to 535-47-1)}

The lower limit of this interval and the positioning of the Valanginian/Hauterivian boundary are discussed above.

Assemblages are characterized by high percentages of Chytroeisphaeridia sp. A, Oligosphaeridium spp. and Subtilisphaera sp. A. In addition microforaminiferal testlinings and large leiospheres are numerically significant throughout the Hauterivian.

The following species are considered to be stratigraphically important:

1. Callaiosphaeridium asymmetricum, a species that has a stratigraphic base in the "mid" Hauterivian of 


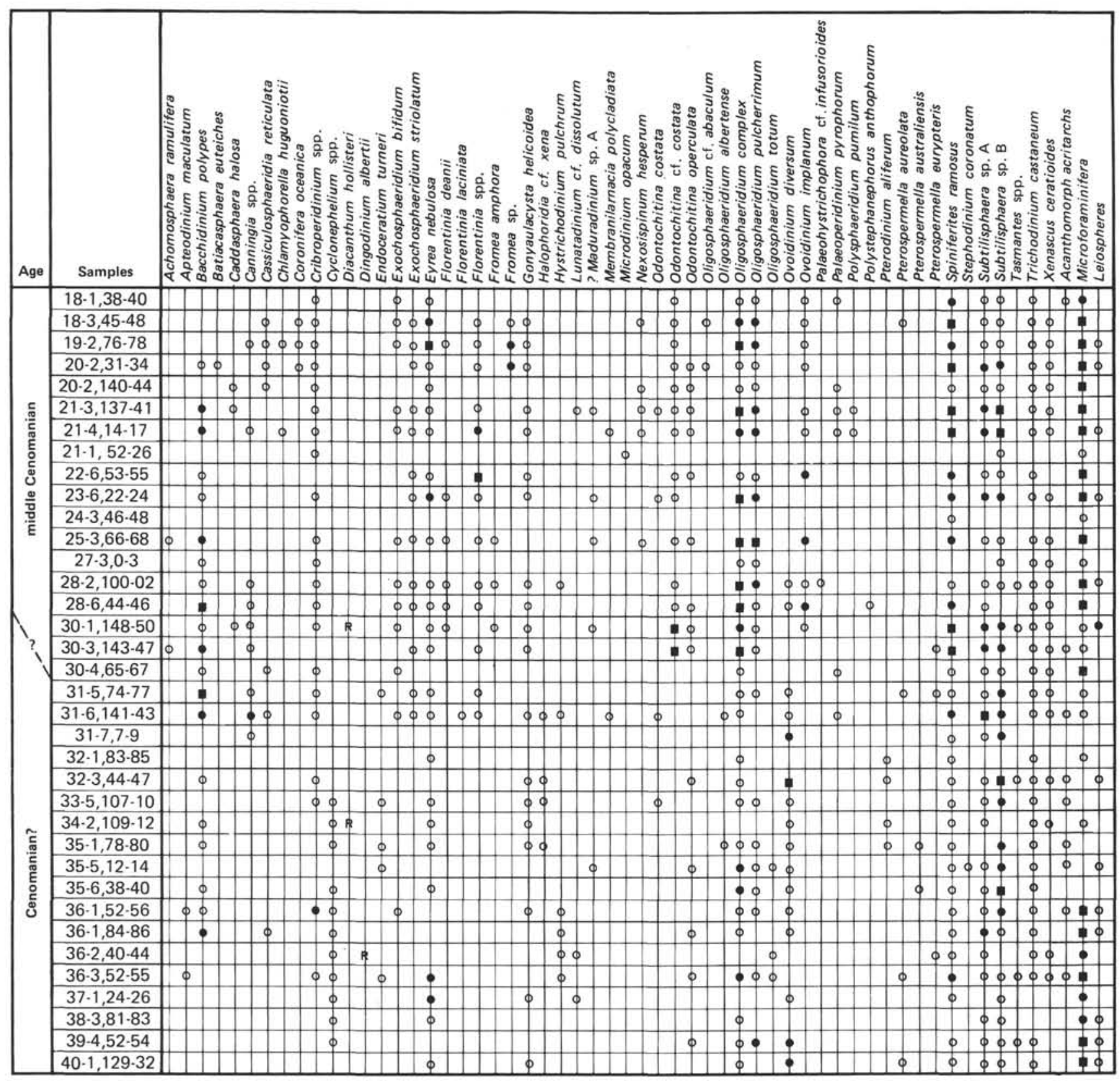

Figure 4. Distribution of marine microplankton in Sections 535-40-1 to 535-18-1. See Figure 2 for symbols and explanation of sample numbers.

northwest Europe (Davey, 1979b), appears in Sample 535-51-1, 101-103 cm.

2. Chlamydophorella sp. A of Davey (1979b) has a top stratigraphic occurrence in the late Hauterivian of eastern England (Davey, 1979b) and occurs up to Section 535-52-3.

3. Gonyaulacysta kostromiensis has its last occurrence in Section 535-47-1; in eastern England (Davey, 1979b) and the European area (Riley, Fenton, pers. obs.), this taxon becomes extinct in the uppermost Hauterivian.

4. Hystrichodinium furcatum makes its last appearance in Section 535-47-1; in offshore western Europe (Fenton, pers. obs.), this species has a total stratigraphic range of upper Valanginian to lower Barremian, but is more numerous within Hauterivian sediments.

5. Muderongia simplex has its last occurrence in Section 535-53-2. Davey (1979b) and the present authors consider that the top occurrence of this species is normally within the upper Hauterivian. Duxbury (1977) has, however, reported it from the lower Barremian of eastern England and Williams and Bujak (1979) have recorded the taxon from the Barremian of offshore eastern Canada.

The change in palynofloras seen in Section 535-51-1 corresponds with a lithostratigraphic boundary (Units IV/III) and is dated as "mid" Hauterivian. This may correspond to a major transgression (possibly of eustat- 


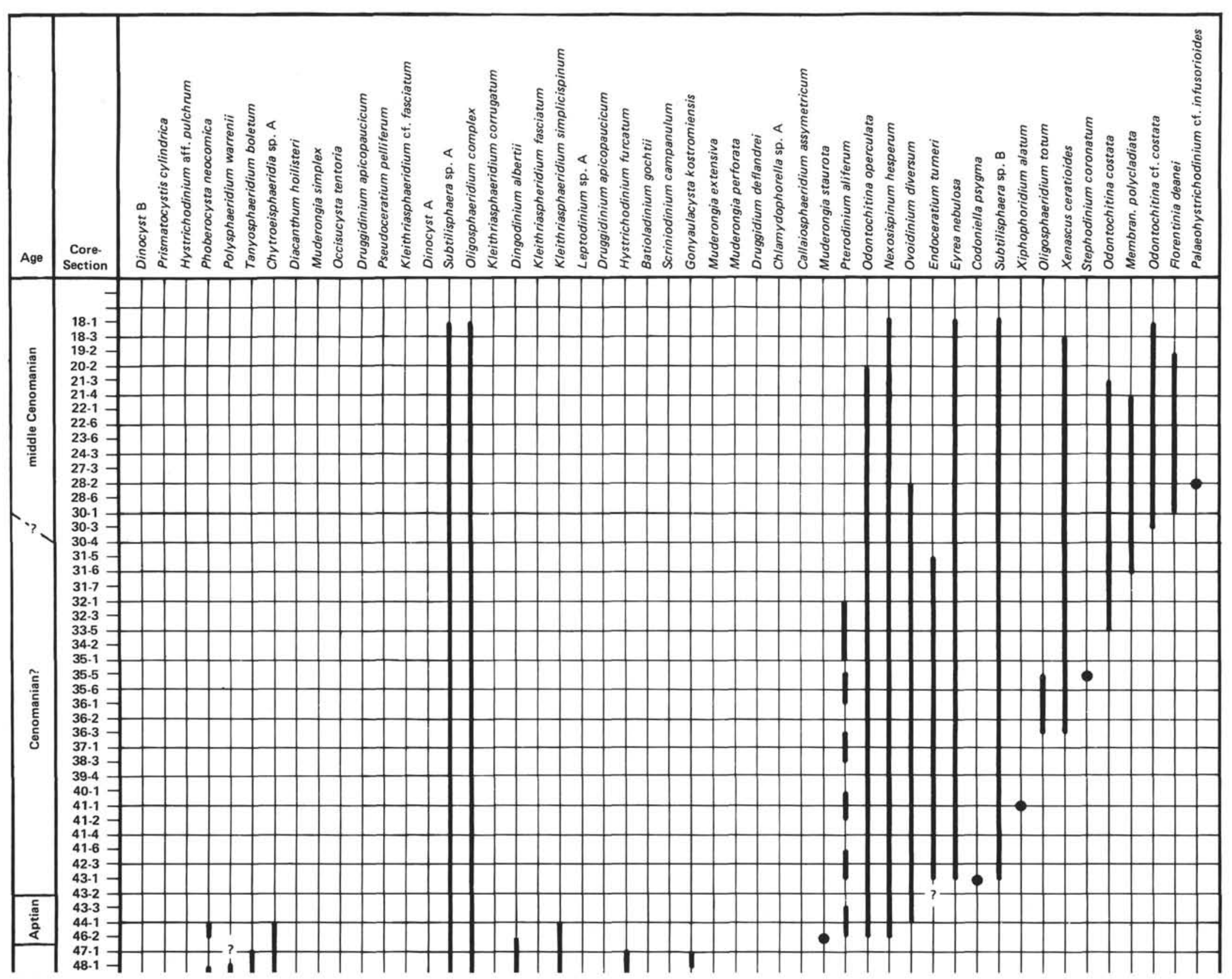




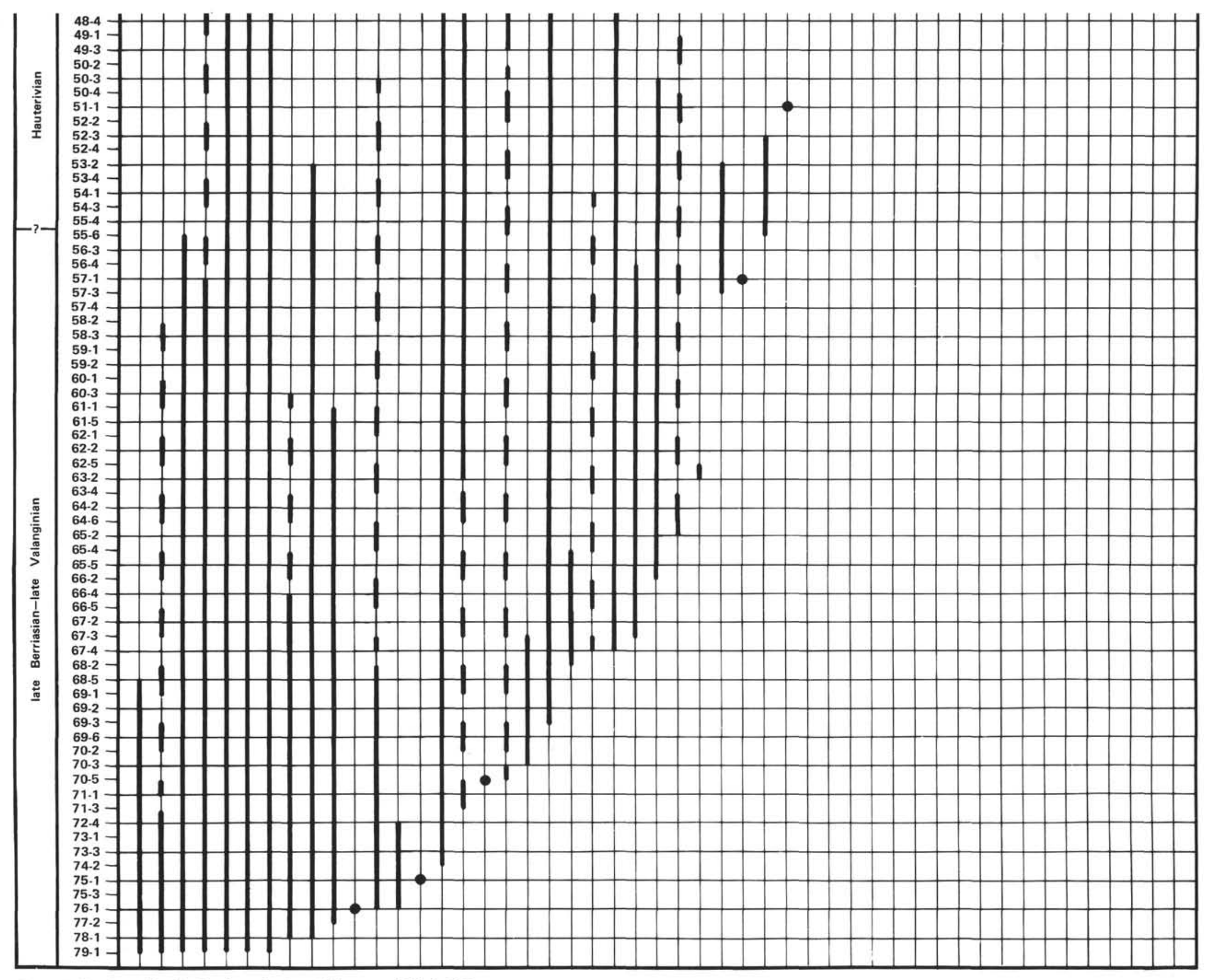


ic origin) in northwestern Europe (Rawson and Riley, 1982).

No positive palynologic evidence has been observed to indicate the presence of Barremian sediments.

\section{Aptian (Sections 535-46-2 to 535-43-3)}

The base of the Aptian is placed, on palynologic criteria, between Sections 535-47-1 and 535-46-2, and an unconformity between the Hauterivian and Aptian is postulated. The dinoflagellate cyst assemblages are, as a whole, characteristically Aptian in composition. Several characteristic and stratigraphically restricted European species (see Davey and Verdier, 1974), however, are lacking. The assemblages are broadly comparable with Aptian material previously described from Sites $400 \mathrm{~A}, 402 \mathrm{~A}$ (Davey, 1979a), and 391 (Habib, 1978).

Palynofloras throughout this interval are characterized by high proportions of Chytroeisphaeridia sp. A, Dingodinium albertii and Subtilisphaera sp. A. in association with microforaminiferal test-linings and large leiospheres.

The following stratigraphically significant species were recovered from this interval:

1. Aptea polymorpha restricted to the Aptian in Western Europe (Verdier, 1975) and reported from the upper Aptian at Hole 402A (Davey 1979a), is restricted to Section 535-44-1.

2. Dingodinium albertii makes its last appearance in the lower Aptian at Hole 400A (Davey, 1979a); in the upper Aptian at Hole 402A (Davey, 1979a); and in Section 535-46-2 in this study.

3. Kleithriasphaeridium simplicispinum has its highest occurrence in Section 535-44-1 and is reported to have a top stratigraphic occurrence in the Aptian (Verdier, 1975). At Hole 400A $K$. simplicispinum is restricted to the Aptian, whereas it occurs in the Aptian and Albian at Hole 402A. The occurrence within the Albian at the latter site appears anomalous and may be due to reworking, as suggested by Davey (1979a, p. 549).

4. Muderongia staurota has a top stratigraphic occurrence in the lower Aptian of northwestern Europe (Verdier, 1975) and is restricted to Section 535-46-2.

5. Nexosispinum hesperum first appears in the upper Aptian at Hole 402A (Davey, 1979a), is restricted to the lower Aptian at Hole 400A (Davey, 1979a), and has a first stratigraphic occurrence in Section 535-46-2.

6. Ovoidinium diversum makes its first appearance close to the lower/upper Aptian boundary at Hole 400A (Davey, 1979a), in the lower Aptian at Hole 402A (Davey, 1979a), and in Section 535-44-1.

7. Phoberocysta neocomica has a top stratigraphic occurrence in the lower Aptian at Site 391 (Habib, 1978), in the uppermost Barremian in western Europe (Verdier, 1975), and in Section 535-44-1.

8. Pterodinium aliferum first appears in Section 535 46-2 and is considered to appear within the lower Aptian of western Europe (Verdier, 1975).

The distribution of these species indicates that Sections 535-46-2 to 535-44-1 may be early Aptian in age and equivalent to the upper part of Habib's (1978) Phoberocysta neocomica Subzone. Section 535-43-3 is upper Aptian, probably uppermost Aptian, and equivalent to the lower part of Habib's (1978) Subtilisphaera perlucida Subzone.

Cenomanian? (Section 535-43-2 to Core 30) and

Rich and diverse microplankton assemblages were recovered from these intervals, generally indicative of an Albian age. Young (this volume), however, reports ammonites of middle Cenomanian age from Core 30 to $17, \mathrm{CC}$. Core 30 to Section 535-43-2 are assigned a questionable Cenomanian age upon the basis of ammonites (Young, this volume). It has therefore been suggested that the palynofloras are almost entirely reworked, with little in situ kerogen. Major reworking would also have to be envisaged to account for the recovery of foraminiferal and nannoplankton assemblages of Albian age from the same interval. This reworking inference is not acceptable to the present authors who, on the following criteria, would maintain an essentially Albian age.

Palynofloras from Section 535-43-2 to 535-18-1 are characterized by large numbers of the following taxa: Bacchidinium polypes, Eyrea nebulosa, Oligosphaeridium complex, $O$. pulcherrimum, Ovoidinium diversum, $O$. implanum, Spiniferites ramosus s.1., Subtilisphaera sp. A, and Subtilisphaera sp. B. Microforaminiferal testlinings are a significant component through much of the interval, becoming especially prominent in Sections 535$30-4$ to $535-18-1$.

Specific age-diagnostic species are discussed below:

1. Codoniella psygma first appears in the upper Aptian at Holes 400A and 402A (Davey, 1979a) and is restricted to Section 535-43-1. Probable examples of $C$. psygma, reported as Hystrichosphaeropsis ovum by $\mathrm{Ha}-$ bib (1972), also occur in the Aptian-Albian of the western North Atlantic.

2. Florentinia deanii first appears in the uppermost Albian (Vraconian) of western Europe (Verdier, 1975); in the middle? Albian at Hole 400A (Davey, 1979a); in Section 535-30-1. The species extends stratigraphically into the upper Cretaceous.

3. Ovoidinium implanum first appears in Section 535-30-1 and is restricted to the upper Albian at Hole 400A (Davey, 1979a). It occurs up to Section 535-18-1.

4. Odontochitina costata appears in the uppermost Albian (Vraconian) in western Europe (Verdier, 1975) and extends into the Campanian. It appears in Section 535-33-5.

5. Palaeoperidinium pyrophorum appears in Section 535-31-6 and is considered to make its first appearance within the Albian (Fenton, pers. obs.). It is most characteristically encountered in late Albian (Vraconian) or younger sediments.

6. Palaeohystrichophora cf. infusorioides first appears in Section 535-28-2. P. infusorioides makes its first appearance in the uppermost Albian (Vraconian) of western Europe (Verdier, 1975) and extends up to the Campanian. Specimens questionably assigned to $P$. infusorioides have, however, been reported from the upper $\mathrm{Al}$ bian (pre-Vraconian) at Hole 400A (Davey, 1979a).

7. Polysphaeridium pumilum appears in Section 53521-4 and makes its first appearance in the upper Albian at Hole 400A (Davey, 1979a). 
8. Pterodinium aliferum makes its last stratigraphic occurrence in the upper Albian (pre-Vraconian) of western Europe (Verdier, 1975) and extends up to Section 535-32-1.

9. Xenascus ceratioides makes its first appearance in Section 535-36-3 and first appears in the lower Albian of western Europe (Verdier, 1975). It is consistent in occurrence at and above Section 535-31-6, a feature characteristic of late Albian (Vraconian) or younger deposits in northwestern Europe (Riley pers. obs.).

10. Endoceratium turneri, a species that has a total range of upper Aptian to upper Albian (pre-Vraconian) of Australia (Morgan, 1980), occurs in Sections 53543-2 to 535-31-5. Rare occurrences of this taxon have been observed within the Cenomanian-uppermost Albian of northwestern Europe (Riley, pers. obs.).

11. Aptea securigera occurs in Section 535-43-1 and is generally considered to be stratigraphically restricted to the Aptian in northwestern Europe (Davey and Verdier, 1974).

12. Trichodinium castaneum appears in Section 53543-1 and has not been recorded from sediments of preAlbian age in northwestern Europe (Verdier, 1975).

13. Stephodinium coronatum, a species with a total stratigraphic range of middle Albian-Turonian in northwestern Europe (Riley, Fenton, pers. obs.) occurs in Section 535-35-5.

Although ammonite evidence suggests that the majority of the palynomorphs encountered in Sections 53543-2 to 535-18-1 are reworked (Young, this volume), little or no evidence has been found to substantiate this. Within Sections 535-43-2 to 535-18-1, the only positive evidence for recycling is seen by the presence of rare specimens of Dingodinium albertii (Section 535-36-2) and Diacanthum hollisteri (Sections 535-34-2 and 535-30-1). The specimens of Nexosispinum hesperum encountered between Sections 535-25-3 and 535-18-3 may also be recycled from the Aptian, although the total stratigraphic range of this taxon has yet to be accurately defined.

The microplankton recovered from Sections 535-43-2 to 535-18-1 suggest the following age subdivision is possible, in contrast to that based upon ammonites (Young, this volume). The occurrence of Endoceratium turneri in Section 535-43-2 indicates a late Aptian or younger age. A late Aptian/early Albian age is suggested in Section 535-43-1 by the simultaneous occurrences of Aptea securigera, Codoniella psygma, and Trichodinium castaneum. Sections 535-42-3 to 535-31-7 contain taxa generally indicative of an early Albian to late Albian (preVraconian) age. Dinocyst assemblages recorded from Sections 535-31-6 to 535-18-1 suggest a late Albian (Vraconian) to Cenomanian? age. The presence of the genus Ovoidinium in Section 535-18-1, if in situ, tentatively suggests an age no younger than Cenomanian, although the genus is more characteristic of Aptian to Albian sediments.

\section{SYSTEMATIC DESCRIPTIONS}

This section is divided in to two parts: The first lists all marine palynomorph species, in alphabetic order, that have been encountered during this investigation. Species figured in the plates are indicated as
Pl. X Fig. Y throughout the list below. Taxonomic discussion of certain species is undertaken in the second part.

Taxonomic nomenclature is principally that used by Stover and Evitt (1978), to which reference should be made for further data.

Achomosphaera neptuni (Eisenack, 1958) Davey and Williams in Davey et al., 1966

Aptea polymorpha Eisenack, 1958

Aptea securigera Davey and Verdier, 1974

Apteodinium maculatum Eisenack and Cookson, 1960

Aprobolocysta varigranosa Duxbury, 1977

Athigmatocysta glabra Duxbury, 1977

Avellodinium falsificum Duxbury, 1977

Bacchidinium polypes (Cookson and Eisenack, 1962) Davey, 1979a

Batioladinium gochtii (Alberti, 1961) Lentin and Williams, 1977. Pl. 2, Fig. 4

Caddasphaera halosa (Filatoff, 1975) Fenton, Neves and Piel, 1980

Canningia spp.

Callaiosphaeridium asymmetricum (Deflandre and Courteville, 1939) Davey and Williams in Davey et al., 1966

Cassiculosphaeridia reticulata Davey, 1969

Chlamydophorella sp. A sensu Davey, 1979b

Chlamydophorella huguoniotti (Valensi, 1955) Davey, 1969

Chlamydophorella trabeculosa (Gocht, 1959) Davey, 1979

Chytroeisphaeridia sp. A. PI. 2, Fig. 7

Chytroeisphaeridia sp. B. Pl. 2, Fig. 8

Chytroeisphaeridia sp. C. Pl. 2, Fig. 5

Codoniella psygma Davey, 1979a. Pl. 3, Figs. 1, 2

Cometodinium sp. A sensu Habib, 1972

Cometodinium? whitei (Deflandre and Courtevelle, 1939) Stover and Evitt, 1978

Coronifera oceanica Cookson and Eisenack, 1958

Crassosphaera hexagonalis Wall, 1965

Cribroperidinium spp.

Ctenidodinium scissum McIntyre and Brideaux, 1980

Ctenidodinium sp.

Cyclonephelium distinctum Deflandre and Cookson, 1955

Cyclonephelium distinctum subsp. brevispinatum (Millioud, 1969) Lentin and Williams, 1973

Cymatiosphaera delicata Cookson and Eisenack, 1971

Cymatiosphaera sp.

Dinocyst sp. A. Pl. 2, Fig. 9

Dinocyst sp. B. Pl. 1, Fig. 9

Diacanthum hollisteri Habib, 1972. Pl. 2, Figs. 1-2

Dingodinium albertii Sarjeant, 1966

Dinogymnium sp. Pl. 1, Figs. 10-11

Discorsia nanna (Davey, 1974) Duxbury, 1977

Druggidium apicopaucicum Habib, 1973

Druggidium rhabdoreticulatum Habib, 1973

Endoceratium turneri (Cookson and Eisenack, 1958) Stover and Evitt, 1978. Pl. 1, Fig. 4

Exochosphaeridium bifidum (Clarke and Verdier, 1967) Clarke et al., 1968

Exochosphaeridium striolatum (Deflandre, 1937) Davey, 1969

Eyrea nebulosa Cookson and Eisenack, 1971. Pl. 4, Fig. 7

Florentinia deanei (Davey and Williams in Davey et al., 1966), Davey and Verdier, 1973

Florentinia laciniata Davey and Verdier, 1973

Florentinia spp.

Fromea amphora Cookson and Eisenack, 1958

Fromea sp. Pl. 3, Fig. 3

Gonyaulacysta helicoidea (Eisenack and Cookson, 1960) Sarjeant in Davey et al., 1966

Gonyaulacysta kostromiensis (Vozzhennikova, 1967) Sarjeant, 1969

Halophoridia cf. xena Cookson and Eisenack, 1962. P1. 3, Fig. 6

Heslertonia cf. heslertonensis (Neale and Sarjeant, 1962) Sarjeant in Davey et al., 1966

Heslertonia sp.

Hystrichodinium furcatum Alberti, 1961

Hystrichodinium pulchrum Deflandre, 1935

Hystrichodinium aff. pulchrum Deflandre, 1935. Pl. 2, Fig. 6

Hystrichodinium voigtii (Alberti, 1961) Davey, 1974

Kleithriasphaeridium eoinodes (Eisenack, 1958) Davey, 1974

Kleithriasphaeridium corrugatum Davey, 1974 
Kleithriasphaeridium fasciatum (Davey and Williams in Davey et al., 1966) Davey, 1974

Kleithriasphaeridium cf. fasciatum (Davey and Williams in Davey et al., 1966) Davey, 1974

Kleithriasphaeridium simplicispinum (Davey and Williams in Davey et al., 1966) Davey, 1974

Leptodinium sp. A sensu Williams and Bujak, 1979

Leptodinium sp. B. Pl. 4, Fig. 3

Lithodinia cf. bulloidea (Cookson and Eisenack, 1960) Gocht, 1976

Lunatodinium cf. dissolutum Brideaux and McKintyre, 1973

Maduradinium? sp. A sensu Davey, 1978

Membranilarnacia polycladiata Cookson and Eisenack in Eisenack, 1973

Membranosphaera sp. A sensu Davey, 1979a

Microdinium opacum Brideaux, 1971

Millioudodinium spp.

Muderongia extensiva Duxbury, 1977. Pl. 1, Fig. 6

Muderongia perforata Alberti, 1961

Muderongia simplex Alberti, 1961

Muderongia staurota Sarjeant in Davey et al., 1966

Muderongia spp.

Nexosispinum hesperum Davey, 1979a

Occisucysta tentoria Duxbury, 1977

Odontochitina costata Alberti, 1961

Odontochitina cf. costata Alberti, 1961. Pl. 3, Figs. 8, 9

Odontochitina operculata (Wetzel, 1933) Deflandre and Cookson, 1955

Oligosphaeridium cf. abaculum Davey, 1979. Pl. 3, Fig. 5

Oligosphaeridium albertense (Pocock, 1962) Davey and Williams in Davey et al., 1966

Oligosphaeridium complex (White, 1842) Davey and Williams in Davey et al., 1966

Oligosphaeridium pulcherrimum (Deflandre and Cookson, 1955) Davey and Williams in Davey et al., 1966. Pl. 1, Fig. 8

Oligosphaeridium totum Brideaux, 1971

Oligosphaeridium sp. A sensu Williams and Bujak, 1979

Omatia sp. Pl. 1, Figs. 1-3

Ophiobolus sp.

Ovoidinium diversum Davey, 1979b. Pl. 1, Fig. 7

Ovoidinium implanum Davey, 1979b. Pl. 3, Fig. 4, Pl. 4, Fig. 8

Palaeohystrichophora cf. infusorioides Deflandre, 1935

Palaeoperidinium cretaceum Pocock, 1962

Palaeoperidinium pyrophorum (Ehrenberg 1838) Deflandre, 1935

Pareodinia ceratophora Deflandre, 1947

Phoberocysta neocomica (Gocht, 1957) Millioud, 1969. Pl. 4, Figs. 1, 4

Phoberocysta tabulata Raynaud, 1978

Polysphaeridium pumilum Davey and Williams in Davey et al., 1966

Polysphaeridium warrenii Habib, 1976. Pl. 2, Fig. 3

Polysphaeridium sp. A sensu Williams and Bujak, 1979

Prismatocystis cylindrica Habib, 1970. PI. 4, Fig. 6

Prolixosphaeridium granulosum (Sarjeant, 1962) Davey et al., 1966

Pseudoceratium pelliferum Gocht, 1957. PI. 1, Fig. 5

Pterodinium aliferum Eisenack, 1958

Pterospermella aureolata (Cookson and Eisenack, 1958) Eisenack 1972

Pterospermella australiensis (Deflandre and Cookson, 1955) Eisenack, 1972

Pterospermella eurypteris (Cookson and Eisenack, 1958) Eisenack, 1972

Pterospermella sp. A. Pl. 4, Fig. 2

Pterospermella spp.

Scriniodinium campanulum Gocht, 1959

Senoniasphaera sp. A

Sirmiodinium grossii Alberti, 1961

Spiniferites ramosus (Ehrenberg, 1838) Loeblich and Loeblich, 1966

Spiniferites ramosus ssp. multibrevis (Davey and Williams in Davey et al., 1966) Lentin and Williams, 1973

Stephodinium coronatum Deflandre, 1936

Subtilisphaera sp. A. Pl. 4, Figs. 11, 12

Subtilisphaera sp. B. Pl. 4, Figs. 9, 10

Systematophora sp. cf. S. areolata Klement, 1960 sensu Williams and Bujak, 1979

Tanyosphaeridium boletum Davey, 1974

Tasmanites spp.

Trichodinium castaneum (Deflandre, 1935) Clarke and Verdier, 1967. Pl. 4, Fig. 5
Wallodinium krutzschii (Alberti, 1961) Habib, 1970

Wallodinium lunum (Cookson and Eisenack, 1960) Lentin and Williams, 1973

Xenascus ceratioides (Deflandre, 1937) Lentin and Williams, 1973. Pl. 3, Fig. 7

Xiphophoridium alatum (Cookson and Eisenack, 1962) Sarjeant in Davey et al., 1966

\section{TAXONOMY}

Class Dinophyceae Fritsch, 1929

Order Peridiniales Haeckel, 1894

Genus CHYTROEISPHAERIDIA Sarjeant, 1962 emend Davey, 1979

Type species. C. chytroeides (Sarjeant, 1962) Downie and Sarjeant, 1965 (1964) emend. Davey, 1979.

\section{Chytroeisphaeridia sp. A}

(Plate 2, Fig. 7)

Description. Cyst subspherical to ovoidal in shape, composed of a single layer (autophragm) of moderate thickness $(0.5-1.5 \mu \mathrm{m})$. The autophragm is smooth and hyaline, and appears unstructured internally. Apical, antapical, and lateral structures are lacking. No paracingulum and parasulcus were observed. Archaeopyle formed by loss of a single precingular paraplate (probably $3 \mathrm{in}$.). The detached operculum is often seen within the autophragm. Cyst is prone to folding, thereby obscuring the overall shape and archaeopyle.

Dimensions. (Size range with mean dimension in parentheses): cyst length 40 (47) $58 \mu \mathrm{m}$ (24 specimens measured); cyst width 23 (27) $45 \mu \mathrm{m}$.

Remarks. This species bears closest resemblance to $C$. chytroeides, but differs in shape and size. C. chytroeides also appears to possess a more rigid autophragm. Chytroeisphaeridia sp. A differs from C. pericompsum (Ioannides et al., 1977, 1976; Davey, 1979) in having a thicker hyaline autophragm and being smaller in size.

\section{Chytroeisphaeridia sp. B}

(Plate 2, Fig. 8)

Description. Cyst ovoidal to subspherical in shape, composed of a single layered wall (autophragm) of moderate thickness $(0.5-1.5 \mu \mathrm{m})$. The autophragm possesses a reticulate ornament of low relief and is hyaline. Apical, antapical, and lateral structures are lacking. No paracingulum or parasulcus observed. Archaeopyle formed by loss of a single precingular paraplate (probably 3 in.). Operculum may remain attached after excystment.

Dimensions. Cyst length 58 (60) $64 \mu \mathrm{m}$ (10 specimens measured); cyst width 45 (47) $54 \mu \mathrm{m}$.

Remarks. This species is possibly conspecific with Pyxidiniopsis challengerensis Habib, 1976. The latter has been recorded from the Aptian-Barremian (Habib, 1972) and Berriasian-Hauterivian (Habib, 1976) of the western Atlantic.

\section{Chytroeisphaeridia sp. C}

(Plate 2, Fig. 5)

Description. Cyst ellipsoidal in outline, with a single layered wall (autophragm) of moderate thickness $(0.5-1.0 \mu \mathrm{m})$. The autophragm is smooth and occasionally hyaline, appearing to be internally unstructured. It lacks apical, antapical, or lateral structures. No paracingulum or parasulcus observed. Archaeopyle formed by loss of a single precingular paraplate (probably 3 in.). The operculum normally remains attached following excystment.

Dimensions. Cyst length 60 (65) $75 \mu \mathrm{m}$ (6 specimens measured); cyst width 33 (36) $40 \mu \mathrm{m}$.

Remarks. This species is similar to Chytroeisphaeridia sp. A in general morphology, but differs in being markedly elongate in outline.

\section{Genus DINOGYMNIUM Evitt, Clarke, and Verdier, 1967}

Type species. D. acuminatum Evitt, Clarke, and Verdier, 1967

Dinogymnium sp.

(Plate 1, Figs. 10-11)

Description. Cyst biconical to subrounded, single layered wall (autophragm). Longitudinal folds ill defined or prominent near paracingu- 
lum becoming indistinct towards the poles. Wall smooth to faintly scabrate. Paracingulum well defined, broad. Parasulcus indistinct, best developed upon hypocyst. Antapical pole may rarely become markedly pointed. Archaeopyle unobserved.

Dimensions. Cyst length 30 (33) $37 \mu \mathrm{m}$ (6 specimens measured); cyst width 21 (27) $33 \mu \mathrm{m}$.

Remarks. Some variation in outline is observed among the specimens encountered. Those from the late Berriasian-early Valanginian appear to possess pointed antapical poles, while those from the Hauterivian are generally subrounded. Wall canals, which often characterize Dinogyminium, appear to be absent.

Some of the specimens encountered may be conspecific with Dinogymnium sp. A. sensu Habib (1972) recorded from the Albian-early Cenomanian at Site 105

Dinogymnium usually characterizes Upper Cretaceous sediments, and if not a result of contamination these occurrences may represent the earliest records of the genus.

\section{Genus FROMEA Cookson and Eisenack, 1958}

Type species. F. amphora Cookson and Eisenack, 1958

Fromea sp.

(Plate 3, Fig. 3)

Description. Cyst ellipsoidal to subrounded in outline. Single-layered wall (autophragm), varying between 1.0-1.5 $\mu \mathrm{m}$ in thickness, being smooth and hyaline. Paracingulum faintly indicated, occasionally reflected by indentation in equatorial outline. Parasulcus unobserved. Circular opening at apex in plan view, concave in lateral view. Operculum occasionally remains attached after excystment.

Dimensions. Cyst length 40 (49) $66 \mu \mathrm{m}$ (28 specimens measured); cyst width 30 (40) $50 \mu \mathrm{m}$.

Remarks. Fromea sp. closely resembles $F$. amphora, but differs in possessing a thinner autophragm, smaller dimensions, and being prone to folding so that specimens are seen in oblique or polar compressions rather than lateral compressions. This results in the circular opening at the apex being seen in plan view rather than in lateral view as in $F$. amphora.

\section{Genus HYSTRICHODINIUM Deflandre, 1935 emend. Clarke and Verdier, 1967}

Type species. $H$. pulchrum Deflandre, 1935

\section{Hystrichodinium aff. pulchrum Deflandre, 1935}

(Plate 2, Fig. 6)

Description. Cyst subspherical to polyhedral, with thin wall. Surface generally scabrate, occasionally becoming graulate. Apex occasionally surmounted by low, rounded apical horn. Paracingulum well defined, parasulcus unobserved. Parasutures vaguely defined by low ridges, with flexuous (often bladelike) processes arising, varying in length between 10-24 $\mu \mathrm{m}$. Processes distally closed and pointed. Paratabulation indistinct. Archaeopyle unobserved.

Dimensions. Cyst length 26 (31) $35 \mu \mathrm{m}$ (12 specimens measured); cyst width $22(28) 32 \mu \mathrm{m}$.

Remarks. These specimens are distinguished by their small size and relatively large flexuous processes.

\section{Genus LEPTODINIUM Klement, 1960 emend Stover and Evitt, 1978}

Type species. L. subtile Klement, 1960

\section{Leptodinium sp. B}

(Plate 4, Fig. 3)

Description. Cyst spherical, wall apparently single layered (autophragm), scabrate to infrapunctate. Paracingulum distinct, laevorotatory, apparently undivided. Parasulcus unobserved. Gonyaulacean paratabulation defined by distinct parasutures. Parasutural crests (approx. 3-4 $\mu \mathrm{m}$ high) scabrate, or occasionally minutely perforate surmounted by small rounded spines. Crests upon the hypocyst occasionally become markedly trabeculate. Archaeopyle precingular, formed by loss of paraplate 3 in.

Dimensions. Cyst length $48 \mu \mathrm{m}$ (single specimen); cyst width $46 \mu \mathrm{m}$.

Remarks. This species differs from other species of Leptodinium in the morphology of the parasutural crests.

\section{Genus ODONTOCHITINA Deflandre, 1935 emend. Davey 1970}

Type species. O. operculata (O. Wetzel, 1933) Deflandre and Cookson, 1955

Odontochitina cf. costata Alberti, 1961

(Plate 3, Figs. 8-9)

Description. Cavate cyst, ceratioid in outline, with apical, antapical, and single lateral horns. Endophragm and periphragm normally closely adpressed, except at base of horns. Endophragm thin, smooth, and nontabulate. Small rounded apical protrusion may be present. Periphragm thin, scabrate to faintly granulate, nontabulate. Small rounded or elongate perforations present on horns, principally developed at their midpoints. Horns frequently possess markedly inflated lower portions, becoming constricted at their midpoint before tapering to pointed or slightly rounded tips. Second, short antapical horn very rarely developed. Paracingulum and parasulcus indistinct. $\mathrm{Ar}$ chaeopyle apical.

Dimensions. Cyst length 85 (109) $120 \mu \mathrm{m}$ (16 specimens measured); cyst width 33 (39) $45 \mu \mathrm{m}$.

Remarks. These specimens are closely comparable with $O$. costata, but differ chiefly by the inflated bases of the apical, antapical, and lateral horns.

\section{Genus OLIGOSPHAERIDIUM Davey and Williams in Davey} et al. 1966

Type species. O. complex (White, 1842) Davey and Williams in Davey et al., 1966

\section{Oligosphaeridium ef. abaculum Davey, 1979}

(Plate 3, Fig. 5)

Remarks. Two partially fragmented specimens were recovered bearing some resemblance to O. abaculum Davey, 1979. Overall morphology is similar to that of $O$. complex but the specimens have a paratabulation weakly defined by unornamented pandasutural areas. The only species of Oligosphaeridium that possesses a definable paratabulation are $O$. abaculum and $O$. verrucosum, Davey (1979a), but in the former species the parasutures are defined by very low ridges, in the latter by aligned granules.

\section{Genus SUBTILISPHAERA Jain and Millepied, 1973}

Type species. S. senegalensis Jain and Millepied, 1973

Subtilisphaera sp. A

(Plate 4, Figs. 11-12)

Remarks. Abundant specimens were encountered throughout the Lower Cretaceous sequence displaying a wide variety of transitional morphological features. Specimens included within Subtilisphaera sp. A may be conspecific with $S$. perlucida (Alberti, 1961); S. scabrata Jain and Millepied, 1973; S. senegalensis Jain and Millepied, 1973; and $S$. terrula (Davey, 1974). Because of the occurrence of numerous transitional morphotypes between the species listed above, no attempt has been made to speciate the specimens incorporated within Subtilisphaera sp. A.

\section{Subtilisphaera sp. B}

(Plate 4, Figs. 9-10)

Remarks. Specimens assigned to Subtilisphaera sp. B may be conspecific with $S$. cheit Below, 1981 and $S$. ventriosa (Alberti, 1961) sensu Jain and Millepied, 1973. Wide morphologic variation precludes accurate specific assignment.

Dinocyst sp. A

(Plate 2, Fig. 9)

Description. Cyst ellipsoidal in outline. Wall smooth. Cyst surface entirely covered by low muri that form predominantly polygonal lumina. Processes $(8-10 \mu \mathrm{m})$ arise along muri, but principally from gonal areas and support a very thin, delicately perforate ectophragm. Parcingulum, parasulcus unobserved. Archaeopyle appears to be apical, with the operculum remaining attached.

Dimensions. Cyst length $60 \mu \mathrm{m}$ (single specimen); cyst width $33 \mu \mathrm{m}$.

Remarks. This morphotype differs from all other genera by its overall morphology. Some comparison can be made with Valensiella Ei- 
senack, 1963, but the latter differs in possessing a closely adpressed ectophragm. Specimens of Dinocyst sp. A have been encountered within the Valanginian of the North Sea area (Fenton, pers. obs.).

\section{Dinocyst sp. B \\ (Plate 1, Fig. 9)}

Description. Small, spherical proximate cyst, with faintly scabrate autophragm. Ornament consists of solid, acuminate processes, which vary in length between 5 and $11 \mu \mathrm{m}$. These processes may be partially aligned along parasutures or intratabular in distribution. Paratabulation indistinct. Paracingulum and parasulcus unobserved. No apical, antapical, or lateral horns present. Archaeopyle formed by loss of an unknown number of precingular paraplates leaving a lingula, composed of the anterior sulcal and apical regions.

Dimensions. Cyst diameter 17 (19) $26 \mu \mathrm{m}$ (10 specimens measured).

Remarks. A distinctive feature of this cyst is its small size, which, when the archaeopyle is undeveloped, makes it appear similar to an acritarch. It differs from other genera, such as Dissiliodinium Drugg, 1978 and Lingulodinium Wall, 1967 by its small size, solid processes, and apparent lack of paratabulation.

\section{Incertae Sedis}

Genus HALOPHORIDIA Cookson and Eisenack, 1962

Type species. H. xena Cookson and Eisenack, 1962

\section{Halophoridia cf. xena Cookson and Eisenack, 1962}

(Plate 3, Fig. 6)

Description. Shell quadrate to rectangular in outline. Thin walled inner body, smooth to faintly scabrate, and subquadrate with weakly concave sides. Outer layer quadrate to rectangular in outline, sides straight to slightly concave, surface scabrate. No mode of opening observed.

Dimensions. Shell length $30-35 \mu \mathrm{m}$ (2 specimens measured); shell width $27-30 \mu \mathrm{m}$.

Remarks. $H$. cf. xena differs from $H$. xena by possessing a shell that has a quadrate to rectangular outline rather than circular to subcircular. The inner body of $H$. xena also possesses more markedly concave sides.

\section{Class Prasinophyceae \\ Genus PTEROSPERMELLA Eisenack, 1972} 1972

Type species. P. aureolata (Cookson and Eisenack, 1958) Eisenack,

\section{Pterospermella sp. A.}

(Plate 4, Fig. 2)

Description. Body sphaerical and smooth, surrounded by equatorial flange that is smooth to scabrate. Radial folds occasionally developed on flange. Body offset from centre of equatorial flange.

Dimensions. Overall diameter 56-70 $\mu \mathrm{m}$ ( 3 specimens measured).

Remarks. These specimens differ from all published species of Pterospermella in the possession of an offset body.

\section{ACKNOWLEDGMENTS}

The authors would like to acknowledge the encouragement and financial support received from Robertson Research International Ltd. during the course of this work.

\section{REFERENCES}

All taxonomic references to dinocysts not listed below are to be found in Lentin and Williams (1981).
Davey, R. J., 1978. Marine Cretaceous palynology of Site 361, DSDP Leg 40, off southwestern Africa. In Bolli, H. M., Ryan, W. B. F., et al., Init. Repts. DSDP, 40: Washington (U.S. Govt. Printing Office), 883-914.

Davey, R. J., 1979a. Marine Apto-Albian palynomorphs from Holes 400A and 402A, IPOD Leg 48, northern Bay of Biscay. In Montadert, L., Roberts, D. G., et al., Init. Repts. DSDP, 48: Washington (U.S. Govt. Printing Office), 547-578.

Davey, R. J., 1979b. The stratigraphic distribution of dinocysts in the Portlandian (latest Jurassic) to Barremian (Early Cretaceous) of northwest Europe. Am. Assoc. Stratigr. Palynolog. Contrib. Ser., 5B:48-81.

Davey, R. J., and Verdier, J.-P., 1971. An investigation of microplankton assemblages from the Albian of the Paris Basin. Verh. K. Ned. Akad. Wet., Afd. Natuurk. Reeks, 26:1-58: pl. 1-7.

Davey, R. J., and Verdier, J.-P., 1973. An investigation of microplankton assemblages from latest Albian (Vraconian) sediments. Rev. Esp. Micropalaeontol., 5:173-212.

Davey, R. J., and Verdier, J.-P., 1974. Dinoflagellate cysts from the Aptian type sections at Gargas and La Bedoule, France. Palaeontology, 17, 623-653.

Duxbury, S., 1977. A palynostratigraphy of the Berriasian to Barremian of the Speeton Clay of Speeton, England. Palaeontographica, 160:1-15.

Fisher, M. J., and Riley, L. A., 1980. The stratigraphic distribution of dinoflagellate cysts at the boreal Jurassic-Cretaceous boundary. Fourth Int. Palynology Conf., Lucknow (1976-77) Proc., 2: 313-329.

Habib, D., 1972. Dinoflagellate stratigraphy Leg 11, Deep Sea Drilling Project. In Hollister, C. D., Ewing, J. I., et al., Init. Repts. DSDP, 11: Washington (U.S. Govt. Printing Office), 367-426.

Habib, D., 1978. Palynostratigraphy of the Lower Cretaceous section at Deep Sea Drilling Project Site 391, Blake-Bahama Basin, and its correlation in the North Atlantic. In Benson, W. E., Sheridan, R. E., et al., Init. Repts. DSDP, 44: Washington (U.S. Govt. Printing Office), 887-898.

Lentin, J. K., and Williams, G. L., 1981. Fossil dinoflagellates: Index to genera and species, 1981 ed. Bedford Institute Oceanography Rept., B1-R-81-12.

McIntyre, D. J., and Brideaux, W. W., 1980. Valanginian miospore and microplankton assemblages from the northern Richardson Mountains, District of Mackenzie, Canada. Geol. Surv. Can. Bull., 320:1-57.

Morgan, R., 1980. Palynostratigraphy of the Australian Early and Middle Cretaceous. Mem. Geol. Surv. N. S. W. Palaeontol., 18: $1-153$.

Rawson, P. F., and Riley, L. A., 1982. Latest Jurassic/Early Cretaceous events and "late Cimmerian unconformity" in the North Sea area. Am. Assoc. Pet. Geol. Bull., 66(12):2628-2648.

Stover, L. E., and Evitt, W. R., 1978. Analysis of pre-Pleistocene organic-walled dinoflagellates. Stanford Univ. Publ. Geol. Sci., 15: $1-300$.

Verdier, J.-P., 1975. Les kystes de dinoflagellés de la section de Wissant et leur distribution stratigraphique au Crétacé moyen, Rev. Micropaleontol., 17:191-197.

Williams, G. H., and Bujak, J. P., 1979. Palynological stratigraphy of Deep Sea Drilling Project Site 416. In Lancelot, Y., Winterer, E. L., Init. Repts. DSDP, 50: Washington (U.S. Govt. Printing Office), 467-496.

Date of Initial Receipt: August 31, 1982

Date of Acceptance: August 15, 1983 


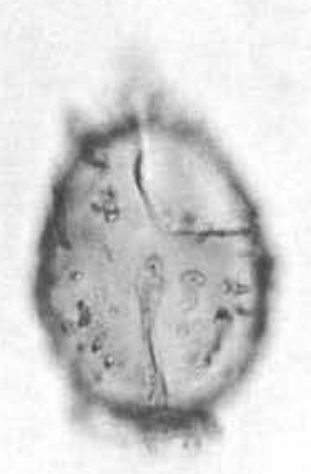

1

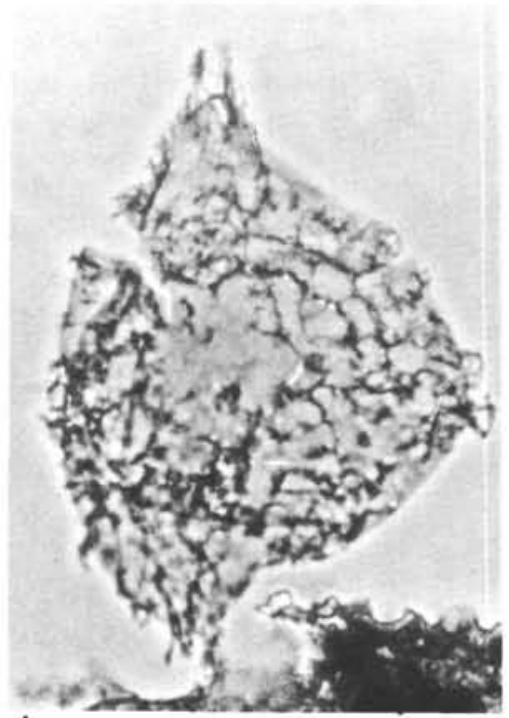

4

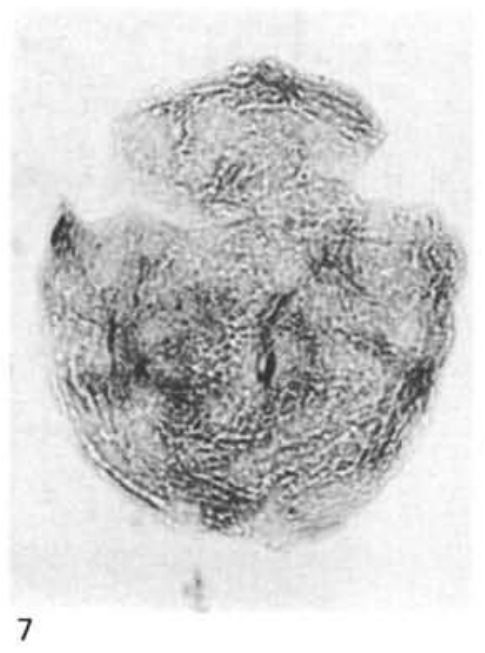

2
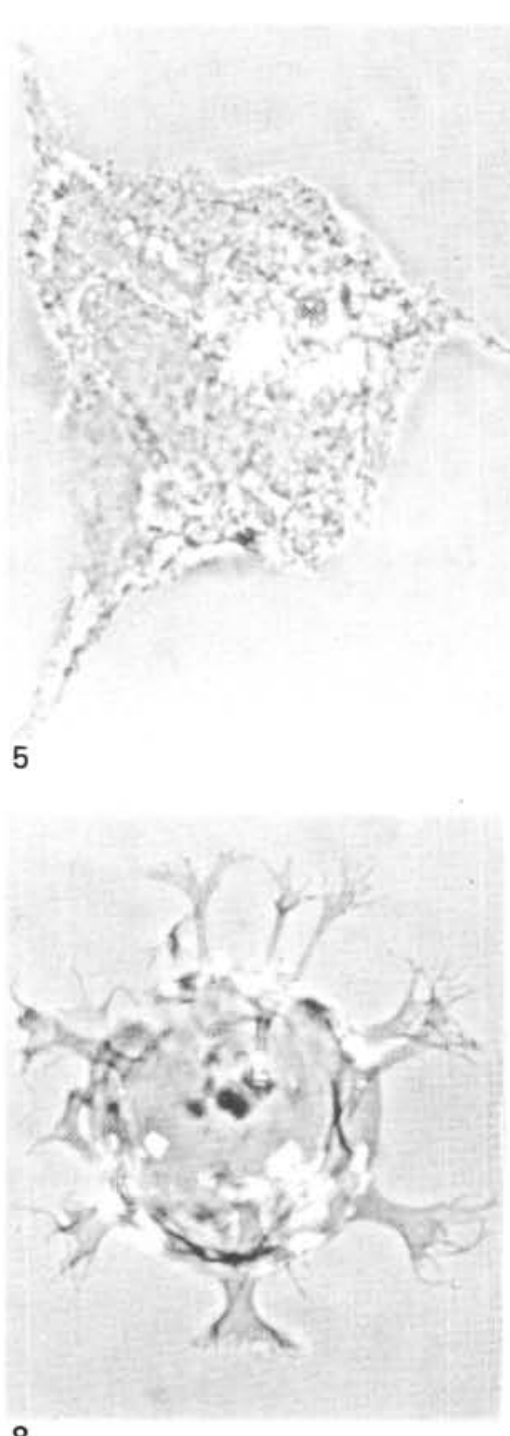

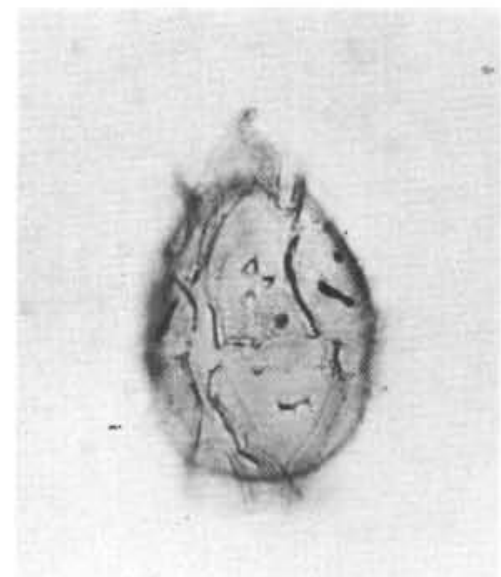

3
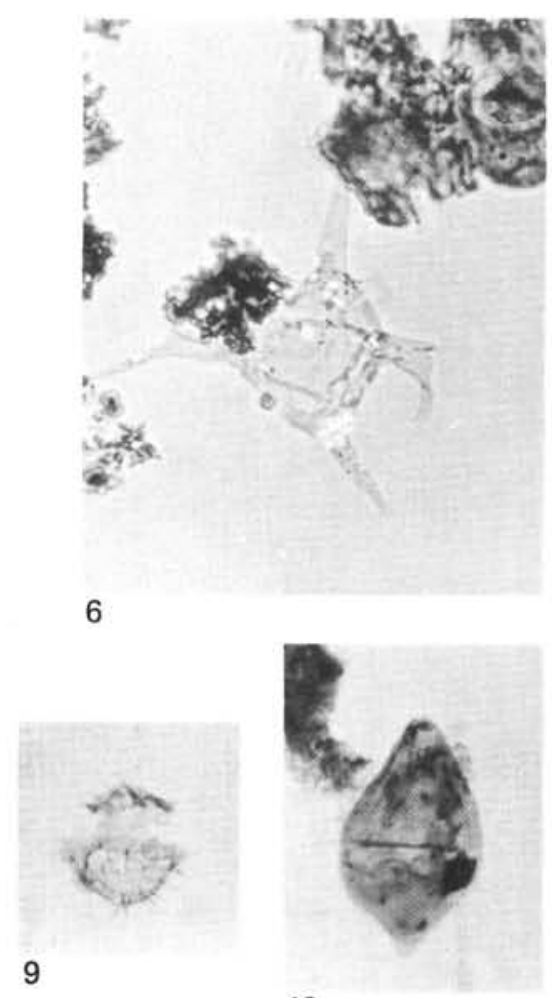

10

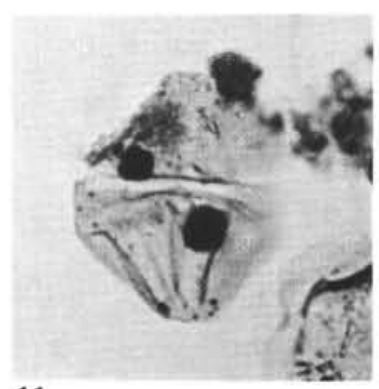

11

Plate 1. (All magnifications $\times 750$ unless otherwise indicated.) 1-3. Omatia sp., Sample $535-46-2,32-34 \mathrm{~cm}$. 4. Endoceratium turneri, Sample 535-42,CC. 5. Pseudoceratium pelliferum, Sample 535-75-3, 117-119 cm. 6. ( $\times 375)$, Muderongia extensiva, Sample 535-63-2, 34-38 cm. 7. Ovoidinium diversum, Sample $535-41-4,122-124 \mathrm{~cm}$. 8. Oligosphaeridium pulcherrimum, Sample 535-55-6, 26-28 cm. 9. Dinocyst sp. B, Sample 535-76-1, 116-119 cm. 10. Dinogymnium sp., Sample 535-79-1, 52-53 cm. 11. Dinogymium sp., Sample 535-74-2, 117-119 cm. 


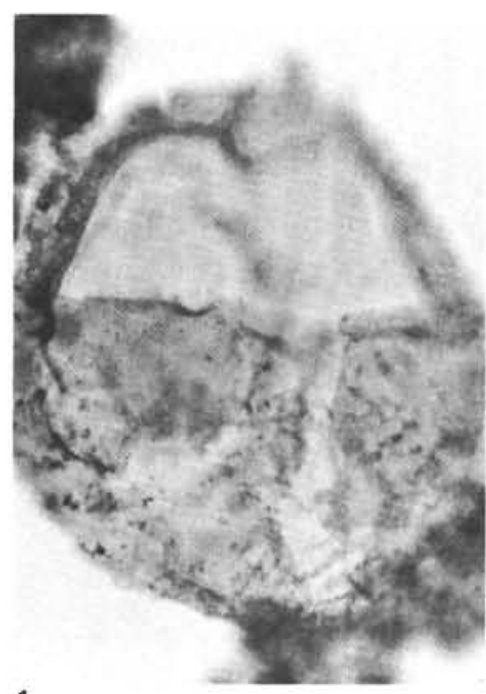

1

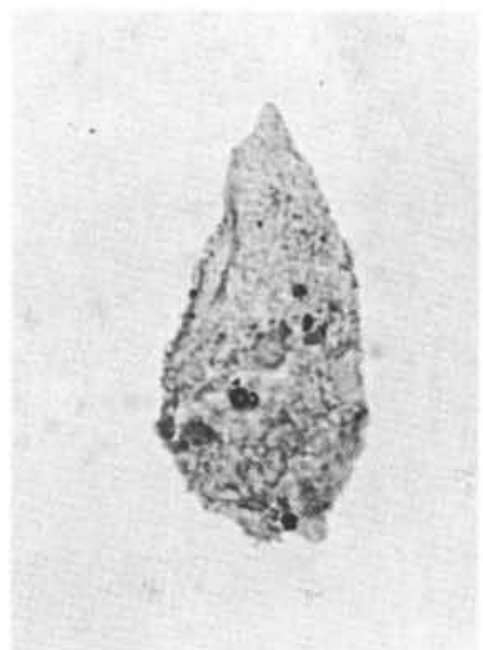

4

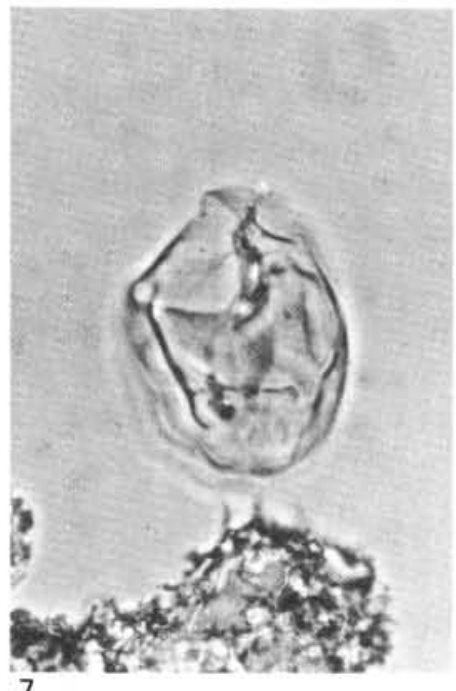

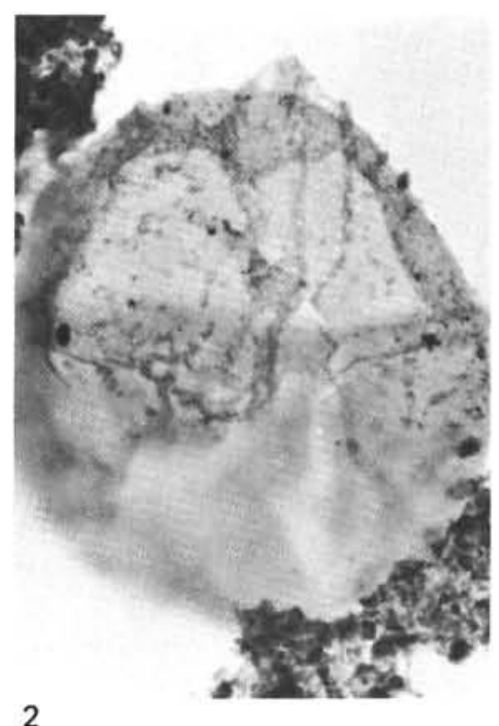

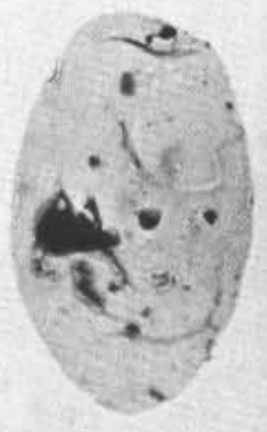

5

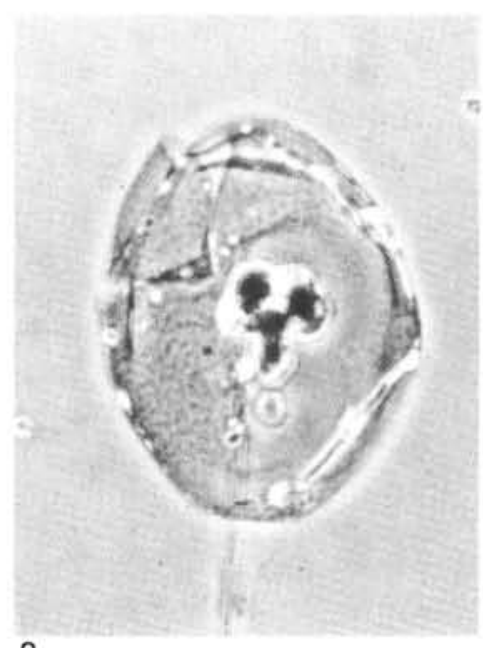

8

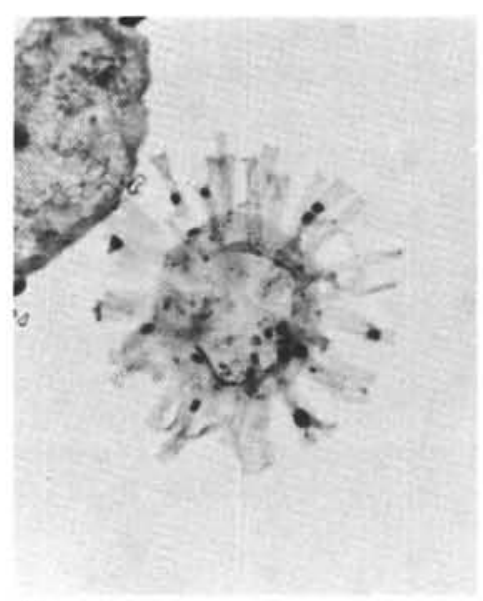

3

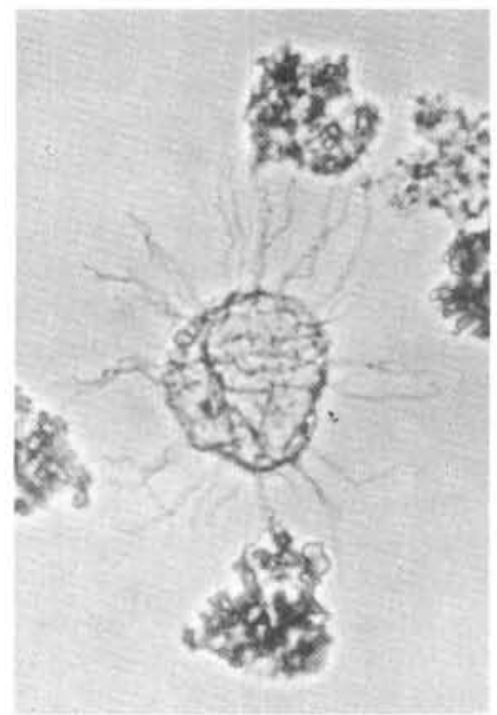

6

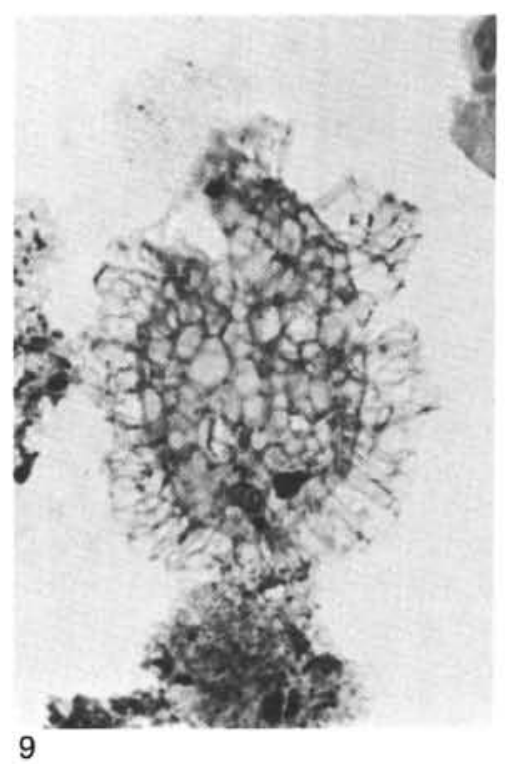

Plate 2. (All magnifications $\times 750$.) 1-2. Diacanthum hollisteri, Sample 535-78-1, 37-39 cm. 3. Polysphaeridium warrenii, Sample 535-78-1, 37$39 \mathrm{~cm}$. 4. Batioladinium gochtii, Sample $535-67-3,77-79 \mathrm{~cm}$. 5. Chytroeisphaeridia sp. C, Sample 535-50-4, 6-8 cm. 6. Hystrichodinium aff. pulchrum, Sample 535-79-1, 52-53 cm. 7. Chytroeisphaeridia sp. A, Sample 535-75-1, 24-28 cm. 8. Chytroeisphaeridia sp. B, Sample 53542 ,CC. 9. Dinocyst sp. A, Sample 535-75-1, 24-28 cm. 


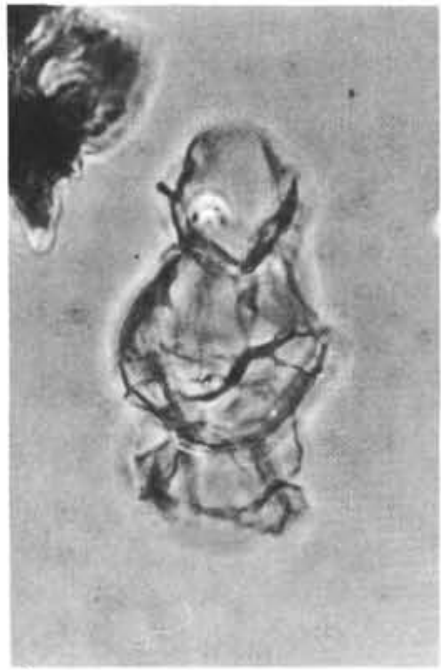

1

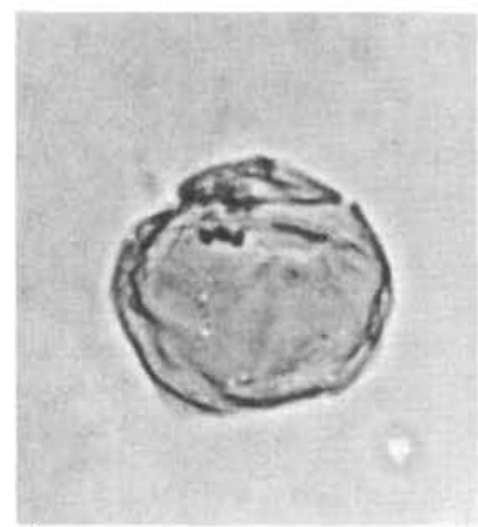

4

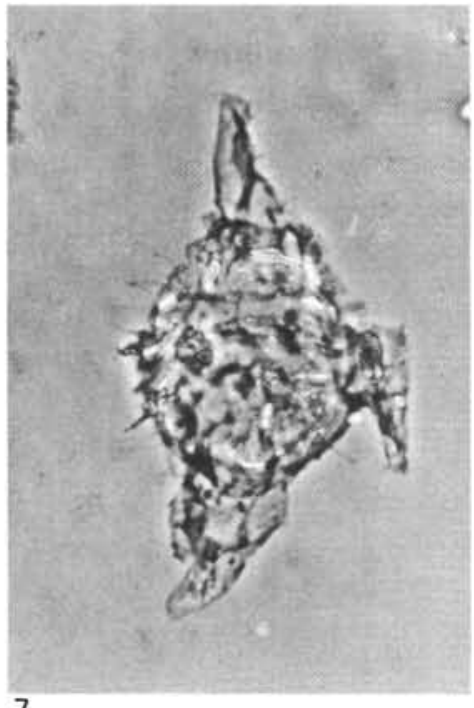

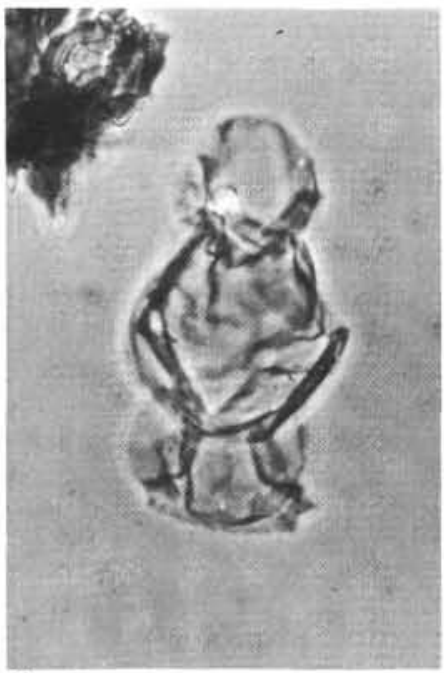

2

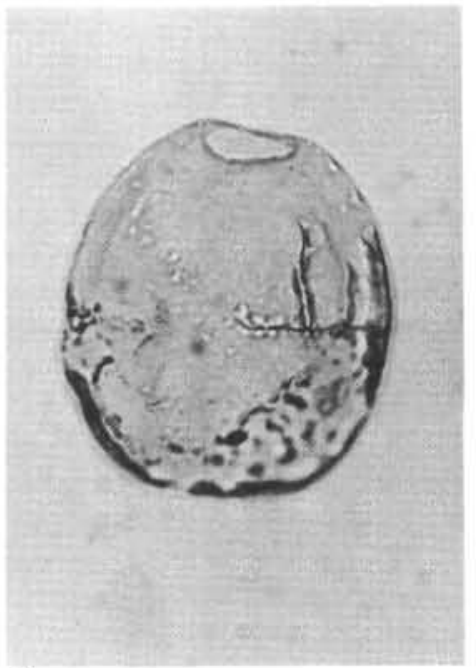

3

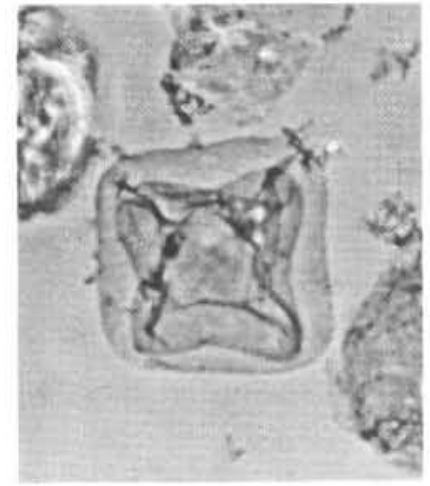

6

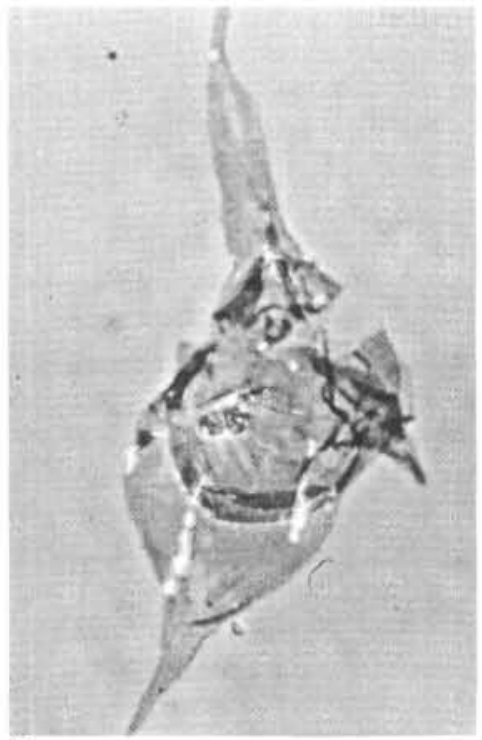

8

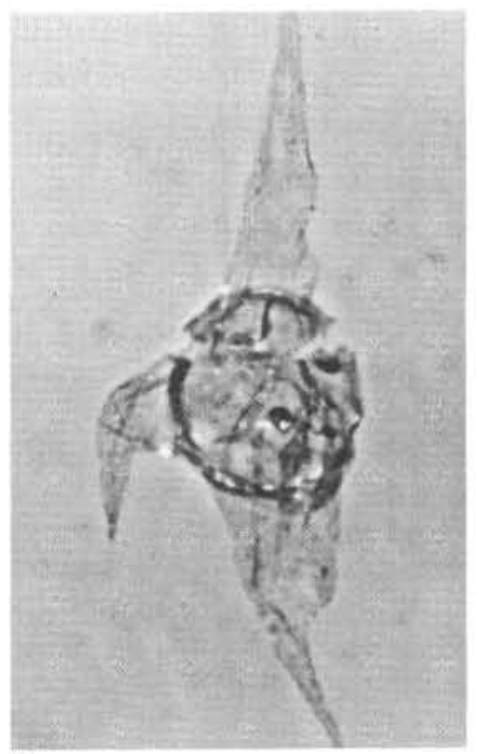

9

Plate 3. (All magnifications $\times 750$.) 1-2. Codoniella psygma, Sample 535-43-1, 77-79 cm. 3. Fromea sp., Sample 535-19-2, 76-78 cm. 4. Ovoidinium implanum, Sample 535-28-6, 44-46 cm. 5. Oligosphaeridium $\mathrm{cf}$. abaculum, Sample 535-20-2, 31-34 cm. 6. Halophoridia cf. xena, Sample 535-31-6, 141-143 cm. 7. Xenascus ceratioides, Sample 535-36-3, 52-55 cm. 8. Odontochitina cf. costata, Sample 535-30-3, 143$147 \mathrm{~cm}$. 9. Odontochitina $\mathrm{cf}$. costata, Sample 535-30-3, 143-147 cm. 

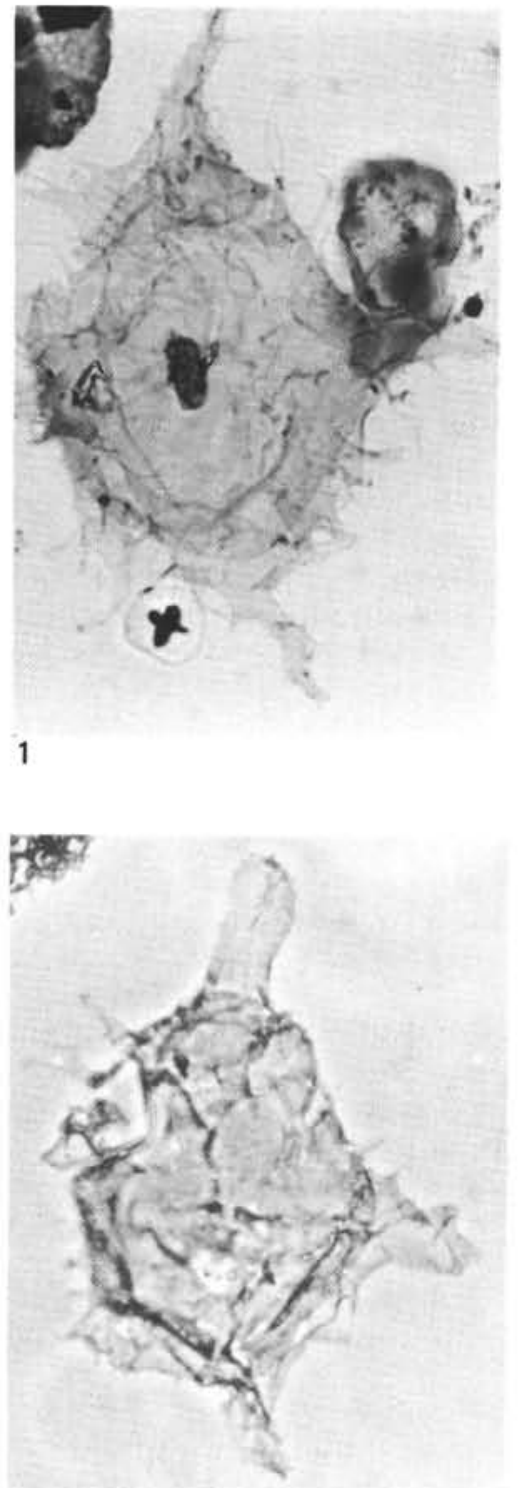

4
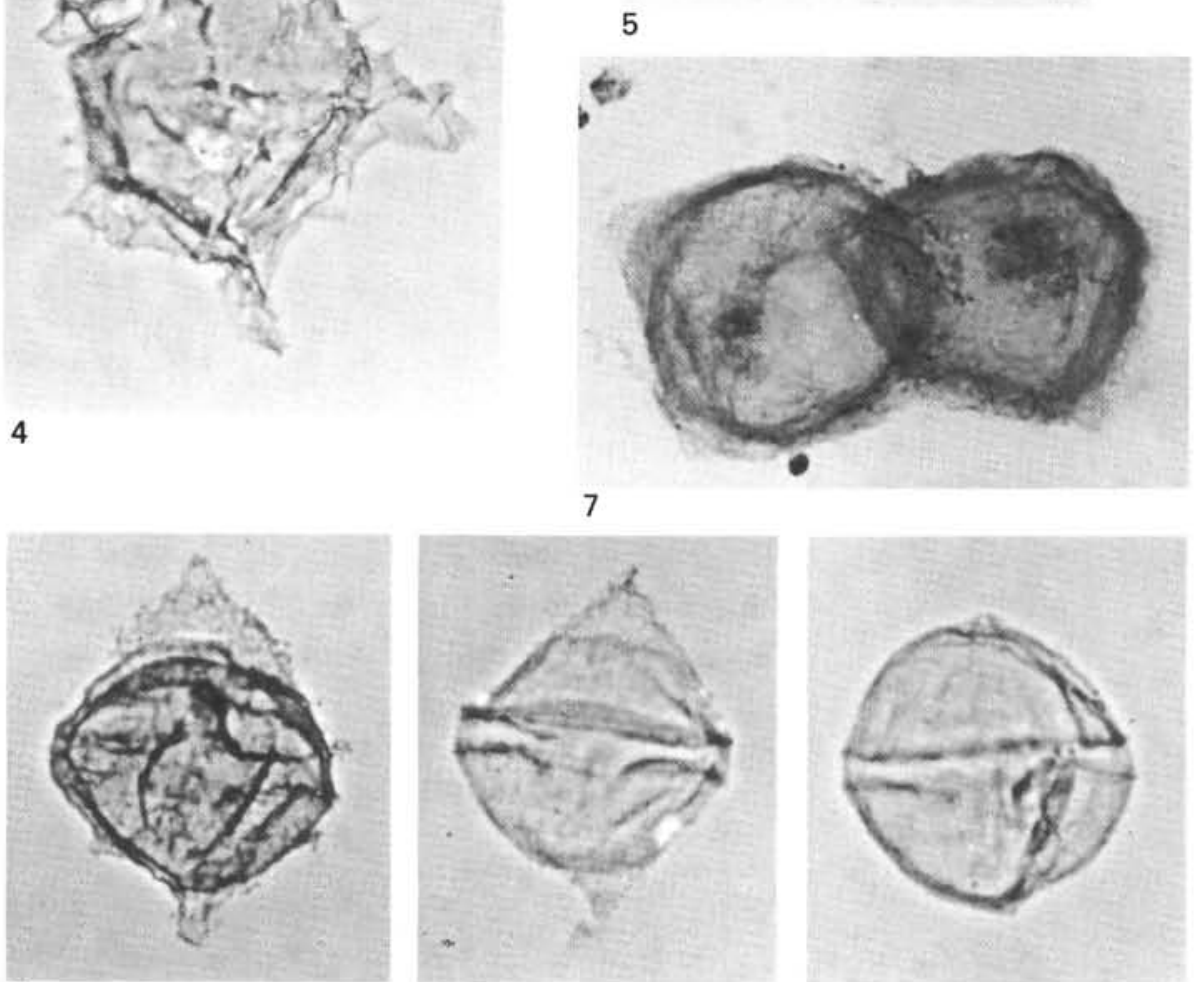

9

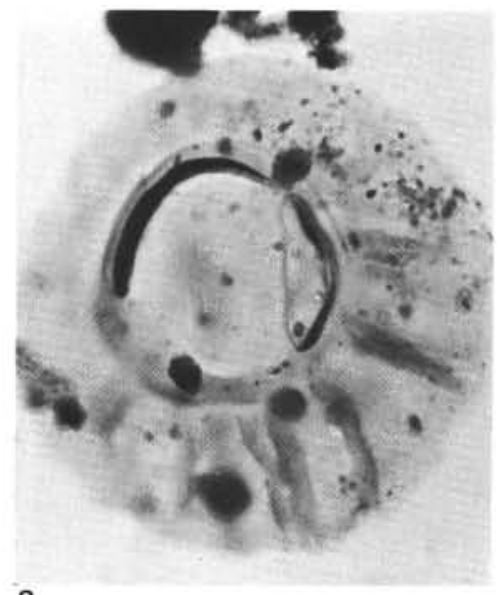

2

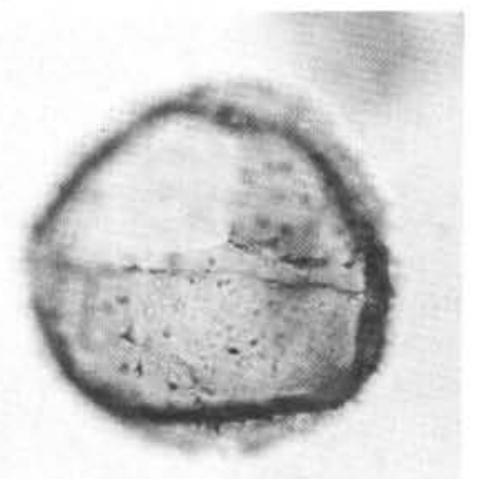

5

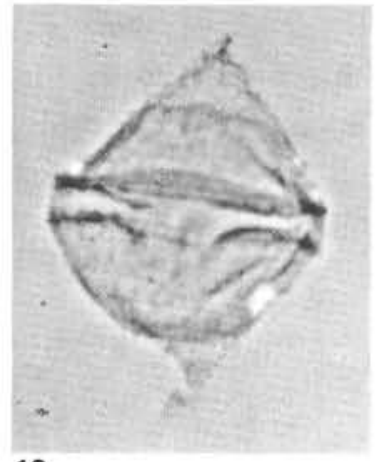

10

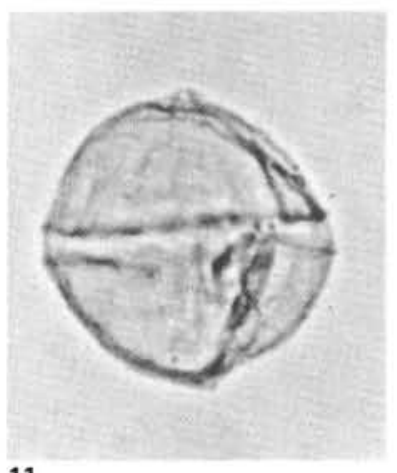

11

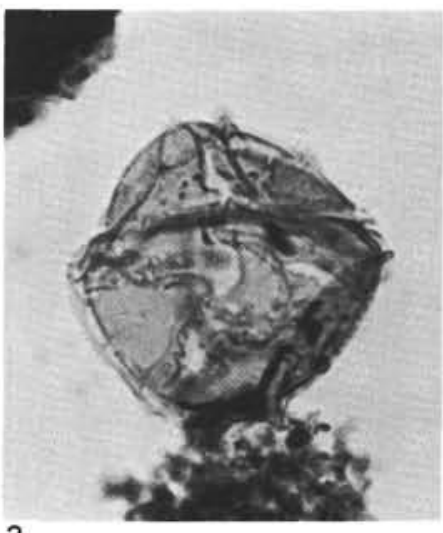

3

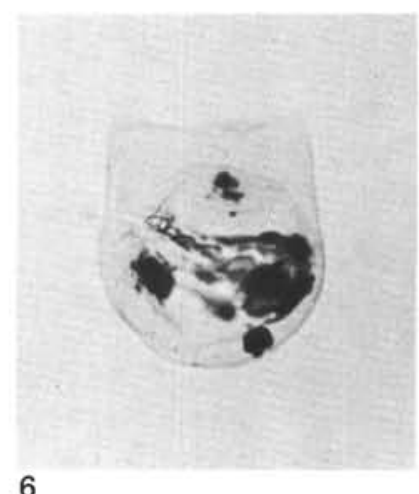

6
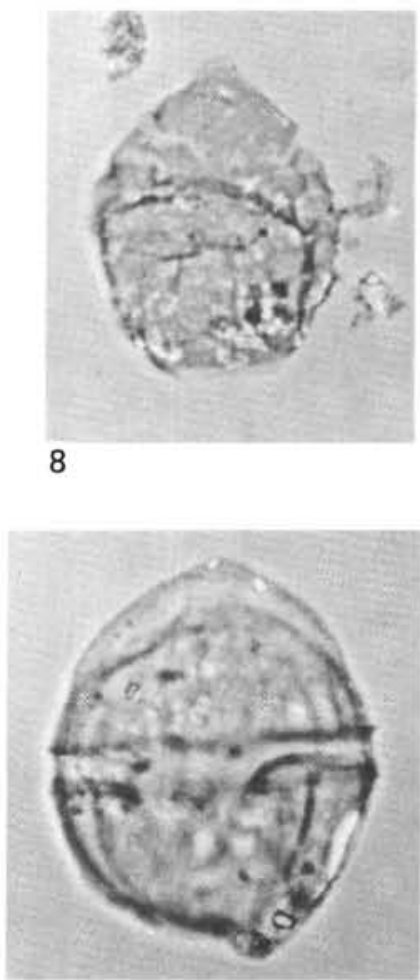

12

Plate 4. (All magnifications $\times 750$.) 1. Phoberocysta neocomica, Sample 535-57-3, 4-6 cm. 2. Pterospermella $\mathrm{sp}$. A, Sample 535-71-1, 137$139 \mathrm{~cm}$. 3. Leptodinium sp. B, Sample 535-69-2, 126-128 cm. 4. Phoberocysta neocomica, Sample 535-76-1, 116-119 cm. 5. Trichodinium castaneum, Sample 535-33-5, 107-110 cm. 6. Prismatocystis cylindrica, Sample 535-75-3, 117-119 cm. 7. Eyrea nebulosa, Sample 535-33-5, $107-110 \mathrm{~cm}$. 8. Ovoidinium implanum, Sample 535-28-6, 44-46 cm. 9. Subtilisphaera sp. B, Sample 535-35-6, 38-40 cm. 10. Subtilisphaera sp. B, Sample 535-35-6, 38-40 cm. 11. Subtilisphaera sp. A, Sample 535-59-2, 84-86 cm. 12. Subtilisphaera sp. A, Sample 535-49-3, 96$97 \mathrm{~cm}$. 